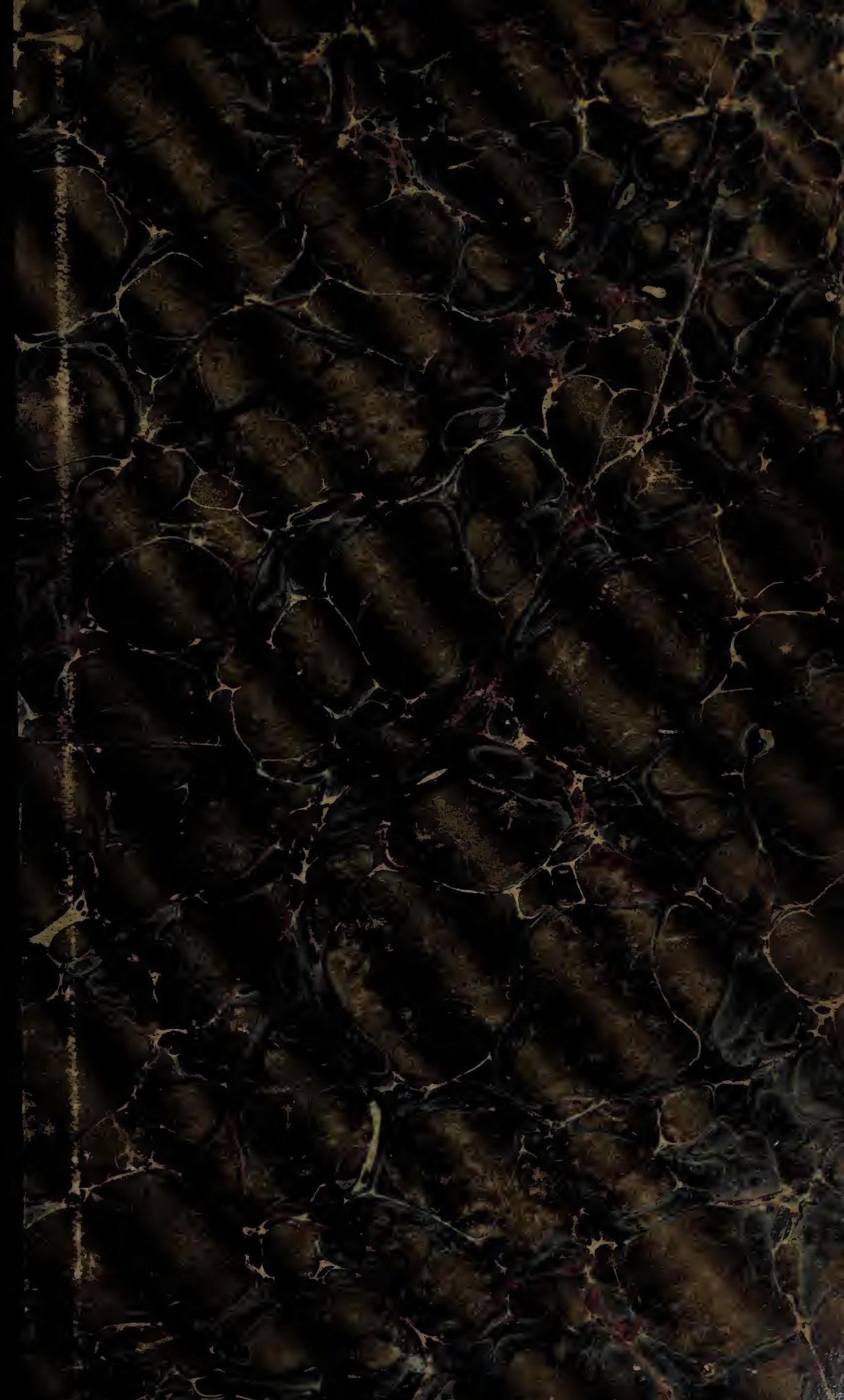




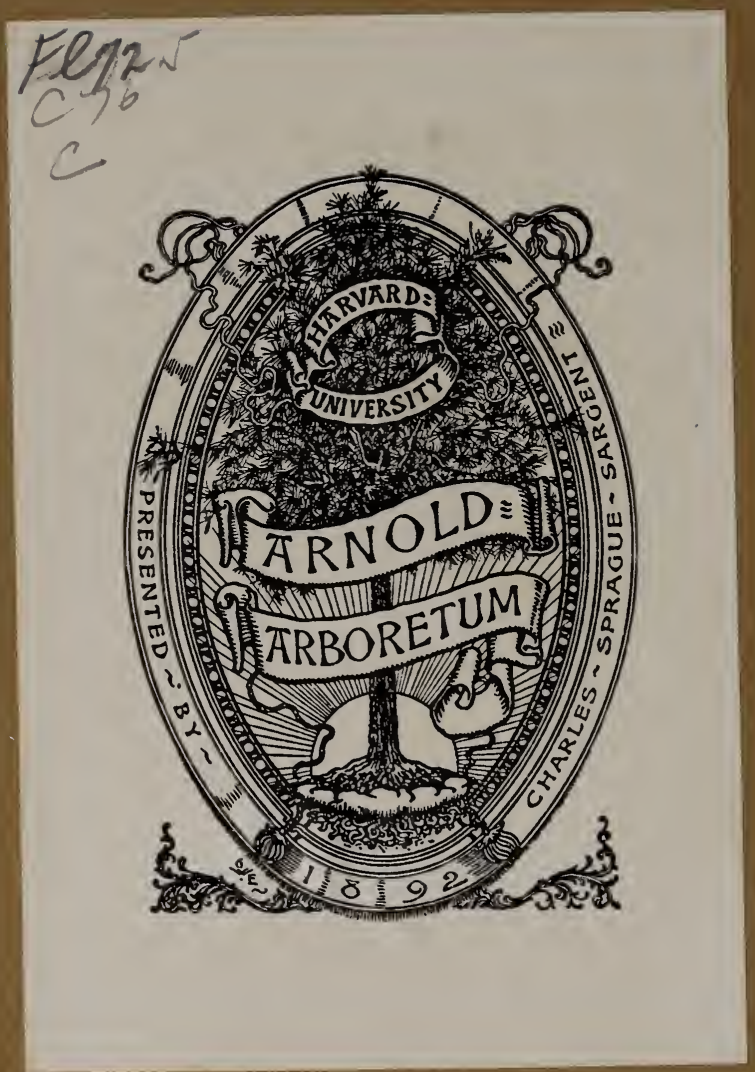



$-$

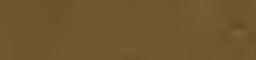






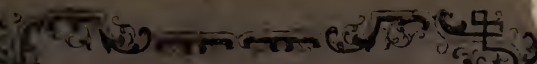

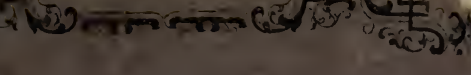

\section{CLAVE ANALITICA}

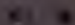

TARA LA DETERMINACION DE IAS FAMILIAS

DE IAS IRANTAS

\section{FA NEROGAMAS}

QUE NACEN : ILVESTRIS

Y CULTIVADAS EN MEXICO,

Por

CASSIANO CONZATTI.

4

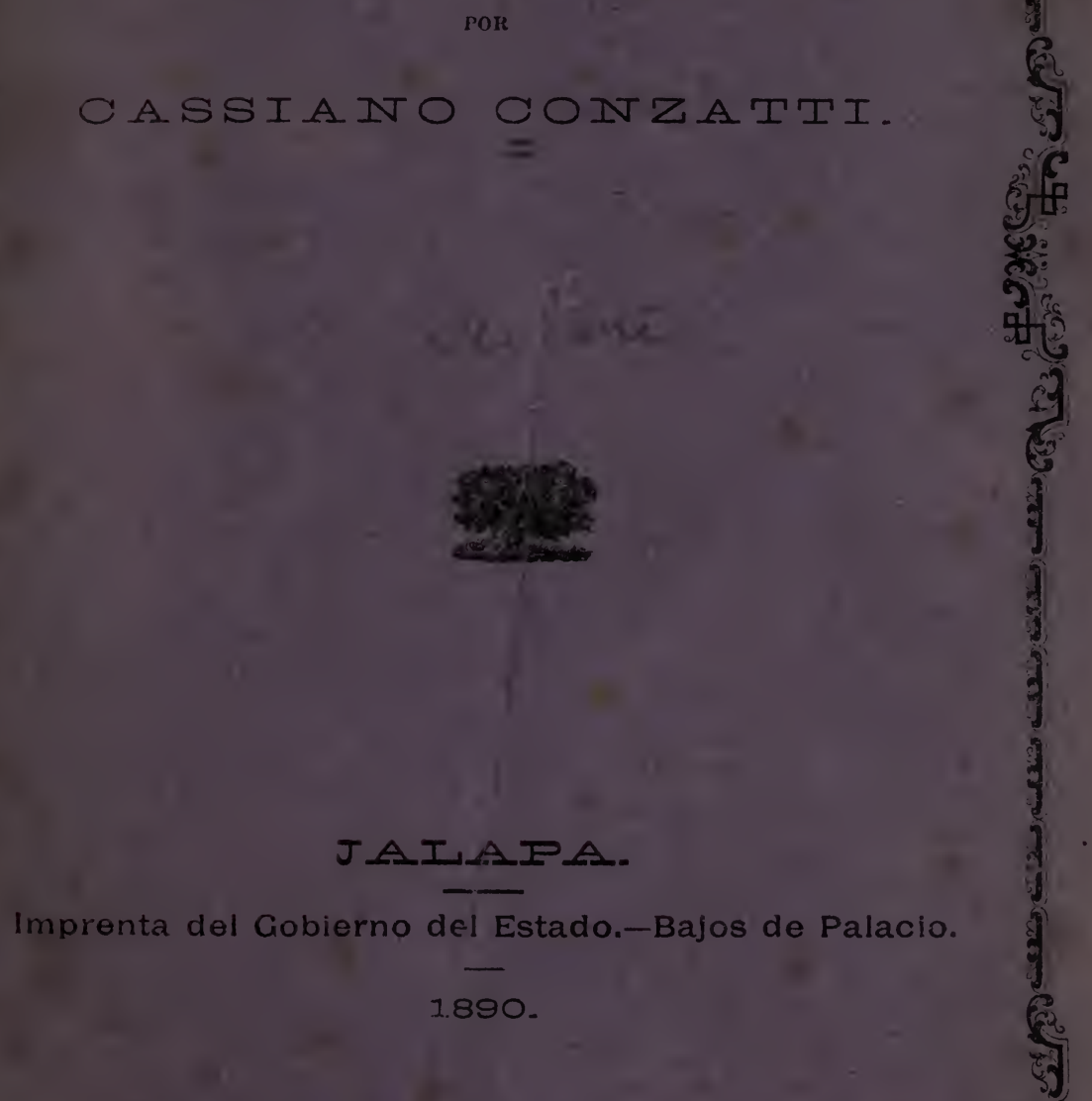

\section{JAIAPA.}





\section{CLAVE ANALITICA}

PARA LA DETERMINACION DE LAS FAMILIAS

DE LAS PLANTAS

\section{FANEROGAMAS}

QUK NACEN SILVESTRES

Y CULTIVADAS EN MEXICO.

Imprenta del Gobierno del Estado.-Bajos del Palacio. $18 \overline{8} 9$. 


$$
\begin{gathered}
\arg \cdot 1911 \\
24949
\end{gathered}
$$


AL EMINENTE NATURALISTA

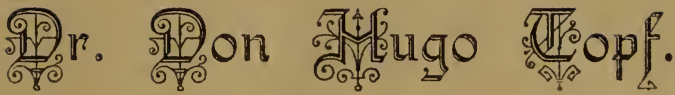

Homenaje de profunda admiración é inmensa gratitud.---Al Maestro, el discípulo agradecido.

e. Conzatti. 



\section{INTRODUCCION.}

( I antes de emprender este humilde ensayo hubiese medido 2.) $\delta$, en su defecto, previsto todas las dificultades que presentaba, es probable que no lo hubiese nunca comenzado.

Aquellos que hayan dedicado algunas horas de estudio á la Botánica, comprenderán sin diula los obstáculos que un trabajo de tal naturaleza presenta, e: primero en mi concepto que de este género ve la luz en México y puede ser quizás que en toda la América latina.

Desde luego manifestaré que está muy lejos de mí la pretensión de presentar un trabajo esencialmente original y mucho menos perfecto; antes bien, creo que es susceptible de muchas reformas y no menos modificaciones.

En cuanto á la originalidad es mi deber manifestar que solo existe en un tratado del - Reino vegetal - impreso en italiano por primera vez en Roma el an̂o de 1879 y formulado por el profesor de botánica en la Universidad de Pisa, D. Teodoro Caruel.

Mas al tomar yo de ese tratado la idea, me valí de la más amplia libertad con el objeto de adaptar mi "Clave" á las necesidades y producciones de la República Mexicana.

Bajo este respecto me atrevo á ofrecer este ensayo hasta cierto punto como original.

En él no sólo se encontrarán las familias de plantas que nacen silvestres y cultivadas en la rica flora mexicana, sino aún las que nacen en las mismas condiciones en casi todos los países latino-colombianos.

Del favor que le dispensare el público dependerá que me resuelva á publicar oportunamente una segunda Clave para la cla- 
sificación de los géneros y de las especies cuyo tratado está ya en preparación.

El estudio de la botánica sólo es provechoso cuando ra acompañado de una atenta observación de todas y cada una de las partes de que constan los vegetales que se estudian, y la presente Clave encierra esta gran ventaja, pues ella estimula notablemente al estudioso y le obliga, por decirlo así, á hacer un análisis completo de todas las plantaș. Para conseguir este objeto, y á fin de evitar confusiones debidas á la existente divergencia de opiniones respecto de la significación de algunos términos botánicos, la hice preceder de una explicación dispuesta por orden alfabético de los vocablos más usados en ella, lo que hará indefectiblemente más provechoso su estudio.

Seguirá al fin un índice alfabético de todas las familias que contenga, acompañadas de los números correspondientes á su intercalación, lo que permitirá apreciar de una sola ojeada los cambios de forma que algunas de éstas sufren á consecuencia, ya del aumento ó disminución de los estambres, ya de otro carácter cualquiera.

Sé muy bien las desventajas que hay en tomar como punto de partida el número de los estambres para la clasificación botánica; pero á mi modo de ver tiene esto la inmensa ventaja de ser el carácter que con más facilidad pueden examinar los principiantes, y por tanto el que más se adapta á todas las inteligencias, y esta es la razón porque lo he preferido.

Desde luego y con el objeto de ir corrigiendo las imperfecciones que pueda tener, suplico á los lectores de mi humilde ensayo se dignen enviarme sus observaciones, las que serán escrupulosamente atendidas, servicio por el cual les anticipo mi gratitud.

Por último, no quiero concluir sin dirigir antes nuevamente mis más expresivas gracias al ilustrado naturalista Dr. D. Hugo Topf por el eficaz cuanto valioso auxilio que se ha dignado impartirme en la formación de la presente Clave, por cuyo servicio le viviré eternamente agradecido.

Jalapa, Octubre de 1889. 


\section{Explicación de algunos términos usados en la "Clave". dispuestos por orden alfabético.}

ACAULE.-Planta cuyas hojas y rama floral parecen nacer de la raíz.

AMENTo.-Es una espiga cuyas flores desnudas, poco vistosas y generalmente diclinas, están protegidas por escamas: encino. ANDroceo.-Conjunto de los estambres ú órganos masculinos. Angrosperia.-Planta cuyos óvulos están encerrados en un ovario: rosa.

Anteras extrorsas.-Siempre que la dehiscencia ó abertura de las anteras esté dirigida hacia el exterior de la flor.

ANTERAS INTRORSAS.-Cuando su dehiscencia mira hacia el centro de la flor.

AqUENIO.-Fruto seco, indehiscente, que encierra una sola semilla y cuyo pericarpio, delgado y membranoso, queda distinto y puede separarse fácilmente de la semilla: girasol.

BAYA. - Fruto indehiscente de mesocarpio carnoso, á menudo suculento, de una ó varias cavidades, sin endocarpio seco: plátano.

BRiCTEAs.-Hojas superiores, relativamente pequeñas, que acompañan la inflorescencia, y que se distinguen de las hojas foliáceas por su forma, color, tamaño y consistencia. De su axila nacen las flores solitarias ó los conjuntos de flores.

BRACTÉOLAS. - Son brácteas de cuya axila no nacen flores.

CAPítulo.-Inflorescencia cuyo eje común, ensanchado en forma cóncava, plana ó convexa, lleva las florecitas sesiles muy apin̂adas. Está rodeado por lo general de un involucro: cardo.

Cápsula.-Fruto dehiscente, uni-ó pluri-locular que se abre por hendiduras longitudinales, ó en su parte superior de varias maneras: azucena.

CARIÓPSIDE.-Fruto indehiscente. monospermo, cuyo pericarpio seco está unido á la semilla: trigo, maiz.

Carpelos distintos.-Ovarios distintos. 
Crus.-Inflorescencia en la que el eje primario acaba en una flor terminal, bajo la cual están insertos en un mismo círculo varios ejes secundarios terminados también por una sola flor y ramificados de la misma manera que el eje primario, siendo de casi igual longitud, de modo que todas las flores se encuentran poco más ó menos en el mismo plano.

Clorófila.-Sustancia verde que se forma bajo la influencia de la luz solar en ciertas células del vegetal y es causa del color vevde de algunas partes del mismo, sobre todo de las hojas.

Cocas.-Expansiones exteriores, convexas y muy marcadas de los diferentes lóculos de un ovario.

Cormibo.-Es un racimo cuyos pedúnculos llegan á la misma altura encontrándose las flores en un mismo plano: sauco.

DeHiscencla.-Acto y manera de abrirse naturalmente los frutos y las anteras.

DEHIS. LOCULICID A. - MIO 10 de abrirse una cápsula mediante hendiduras que se efectúan en la costilla central de las hojas carpelares, de manera oue cada vulea lleva en el centro de su cara interna un tabique: asscenci

DEHIS. SEPTICIDA. - Mocio de abrirse una cápsula mediante helldiduras que se efectúan ¿́ lo largo de los bordes de las hojas carpelares, de manera que los lóculos se separan uno de otro permaneciendo enteros: ricino.

DEHIS. SEPTÍFRAGA.-Variedad de la dehiscencia loculicida que tienelugar cuando los tabiques en vez de acompañar sus valvas respectivas, permanecen en el centro de la cápsula abierta, constituyendo una columna alada: estramonio.

DiCLINA.-Se llama asi la planta que tiene flores masculinas y flores femeninas: calabaza.

Disco.-Anillo más ó menos grueso, ó verticilo de eminencias, escamas ó glándulas, que se encuentra en el fondo de ciertas flores.

Disco EPIGINo.-Es aquel que corona el ovario.

Disco hipogino. - Cuando rodea la base del ovario.

Disco PERigino.-Si rodea el ovario á cierta altura de su base. 
DRUPA.-Fruto indehiscente mono-ó plurispermo, de mesocarpio carnoso, á menudo suculento, y de endocarpio duro ó coriáceo: durazno, ciruela, guinda.

EspáDICE.-Inflorescencia propia de los vegetales monocotiledóneos, reducida á una espiga de flores uni-sexuales sentadas, reunidas sobre un eje común y rodeadas de una espata: aro.

ESPATA.-Bráctea por lo general grande y coloreada que encierra una sola flor ó un conjunto de flores, principalmente el espádice: piña anona.

Espiga.-Inflorescencia cuyo eje común lleva las flores sesiles y sobrepuestas unas á otras: trigo.

EsTAMBRES ANDRóFOROS.-Denominación general dada á los estambres cuyos filamentos se sueldan entre sí formando uno ó varios haces.

EstaMbres DIADELFos.-Se llaman así cuando unidos por sus filamentos forman dos haces, uno de los cuales puede constar de un solo estambre: frijol.

Estambres didinamos.-Dos cortos y dos largos insertos todos en una corola gamopétala: digital.

EsTAMBRES EPIGINOS.-Si se insertan sobre el ovario mismo: plátano, perejil.

Estambres ginandros. - Si están soldados con el estilo, (estigma), formando como un solo cuerpo: aristoloquia.

Estanibes hipoginos. - Son los que se insertan en la base del ovario: adormidera.

ESTAMBRES MONADELFOS.-Siempre que se suelden entre sí por sus filamentos formando un solo haz á manera de tubo cilíndrico al rededor del pistilo: malva.

EsTAMBRES PERIGINOS.-Cuando se insertan en el cáliz: rosa, almendro, granado.

EstAMBRES POLIADELFos.-Si forman, soldados por sus filamentos, más de dos haces: corazoncillo.

Estambres Sinantéreos.-Generalmente cinco reunidos y soldados por sus anteras: cardo.

EstAMBRES TETRADINAMOS:-Dos cortos y cuatro largos: berro, col, rábano. 
Estípite.-Tallo derecho, cilíndrico, que tiene en su vértice un penacho de hojas, á menudo muy grandes, con flores y frutos entre ellas, propio de ciertos monocotiledóneos, sin ramas y cubierto con los restos de las hojas caidas: palmeras.

Estípulas.-Apéndices, generalmente dos, que nacen á los lados de la base del pecíolo: acacia, tilo.

Est. CADUCAS.-Estípulas coriáceas ó membranosas que se caen apenas se ha desarrollado la hoja: higuera.

EsT. FOLIÁCEAS. - Son estípulas persistentes de la consistencia de las hojas ordinarias: pensamiento.

EST. INTERFOLIARES.-Estipulas pertenecientes á hojas opuestas y unidas entre sí por sus bordes de modo que las estipulas de dos hojas distintas están opuestas á las otras dos estípulas de las mismas hojas, formando una cruz con estas últimas: café.

EsT. LIBRES. - Cuando no están unidas entre sí ni forman cuerpo con el pecíolo: pensamiento.

Fascículo.-Es una cima cuyas flores tienen pedúnculos relativamente cortos; éstas son muy apiñadas y se encuentran casi en el mismo plano: clavel.

Filos.-Las diferentes piezas de un perigonio: lirio.

FLor AXILAR.-Es la que nace en la axila de la hoja, esto es, del ángulo formado por ésta con el tallo.

FLor TERMiNAL.-Es aquella que sale de la parte superior del tallo.

Folículo.-Fruto dehiscente, seco, de una sola cavidad, con varias semillas y cuyo pericarpio se abre á lo largo por una sola hendidura: eléboro.

Fruto.-Ovario maduro. Comprende dos partes: el pericarpio, (pared del ovario) y la semilla, (óvulo.) El pericarpio consta algunas veces de tres capas, á saber: el epicarpio ó película exterior, el mesocarpio ó capa intermedia, y el endocarpio ó envoltura inmediata de la semilla.

GAMóFiLo.-Perigonio gamófilo es aquel cuyas piezas (filos) están soldadas entre sí: lirio.

Gimnosperma.-Planta cuyos óvulos no están encerrados en un ovario: pino. 
Gineceo.-Conjunto de los pistilos ú órganos femeninos.

Ginostema.-Órgano constituido por la íntima unión de los estambres, del estilo y estigma, generalmente grueso, que se encuentra en el centro de la flor y que, ó lleva en su extremo superior las dos tecas separadas de una sola antera, ó está rodeada de varias anteras sesiles.

GLUmas. Bractéolas membranosas que acompañan una ó varias flores cuya inflorescencia es una espiga: cebada.

HoJAS PELTADAS. - Son redondeadas y tienen el pecíolo cerca del centro de la superficie inferior de la lámina: mastuerzo.

HOJAS RADICALES. - Son las que nacen al rededor de la base de un tallo: violeta.

Hojas TRÍstiCAS. - Cuando la 4. ${ }^{\mathrm{a}}$ hoja de un tallo provisto de hojas alternas se halla verticalmente sobrepuesta á la 1. a; la 5. á la $2 .^{\mathrm{a}}$; la $6 .^{\mathrm{a}}$ á la $3 .^{\mathrm{a}} \mathrm{y}$ así sucesivamente.

INFLORESCENCIA.-Conjunto de las flores y su disposición en un vegetal.

InvoluCro. - Conjunto circular de bractéolas que se encuentra inmediatamente debajo de una flor solitaria ó de una inflorescencia: girasol, malva, perejil.

Lóculos.-Las cavidades del ovario; así puede ser éste unibi-tri-cuadri-quinque-ó pluri-locular.

Nuez.-Fruto indehiscente, monospermo, de pericarpio seco, grueso y duro, no unido á la semilla: coco, bellota.

OvarIo.-Órgano situado en el centro de la flor; contiene las semillas.

Ovario moNosPERMo.-Ovario que contiene una sola semilla: durazno.

Ovario PAUCispermo.-Ovario que contiene pocas semillas: uva.

OVARIO POLISPERMO.-Ovario que contiene muchas semillas: tabaco.

PẢLEAS.-Brácteas membranosas y secas que se encuentran en la base del ovario de ciertas plantas: cebada, trigo.

Panícula.-Variedad de racimo cuyos ejes secundarios son dé- 
biles, largos y constituyentes á su vez racimos cuyos elementos son espigas pequeñas: avena, panizo.

PAPO.-Corona de escamas, pelitos ó cerditas sobre un aquenio, la cual constituye el cáliz de ciertas flores dispuestas en capítulo: cardo.

PePónide.-Baya que tiene la forma del fruto del melón, del pepino, de la calabaza, de la sandia.

PERIANTO DOBLE.-Cáliz y corola: violeta.

PERIANTO SIMPLE.-Perigonio: livio.

PistiLo.-Organo femenino de la flor; comprende generalmente tres partes: el ovario, el estilo y el estigma.

Placenta. - Lugar donde están fijos los óvulos en el ovario.

Placenta AXILAR. - Manera de estar fijos los óvulos en el centro del ovario; puede haber en este caso un solo óvulo libre ó una columnilla central, columela, que lleva los óvulos: estramonio.

Placenta Parietal.-Manera de estar fijos los óvulos en las paredes de cada lóculo del ovario: violeta.

Plantas DIOICAS. - Epíteto que sirve para calificar las plantas cuyos sexos están separados en individuos distintos: palmera.

Plantas monorcas.-Se dice de las plantas que producen en el mismo tallo flores masculinas y femeninas distintas: calabaza.

RAcimo.-Inflorescencia cuyo eje primario común lleva alternando los ejes secundarios ó pedúnculos de las flores, los que pueden ser sencillos ó ramificados: wva.

Sámara. - Fruto indehiscente, de pericarpio seco que no está soldado con la semilla y que se extiende lateralmente en forma de láminas ó alas membranosas: olmo.

SUB-FRUTESCENTE:-Forma intermedia entre vegetal herbáceo y leñoso.

TALLO FOLIÁcEO.-Es aquel que presenta la forma y contextura de las hojas.

Tecas.-Partes, por lo común dos, de la antera, que encierran el polen: floripondio.

TrRso.-Especie de racimo, varias veces ramificado, que presenta los ejes secundarios de su parte media más desarrollados 
que los de la base y el vértice, lo cual da á esta inflorescencia una forma más ó menos ovóidea: trueno.

UMBELA.-Inflorescencia cuyo eje floral común lleva en su ápice los ejes secundarios, sencillos ó compuestos de la misma manera que el eje primario y cuyas flores se extienden en un mismo plano: perejil.

VALVAS.-Las diferentes piezas que constituyen el pericarpio - de una cápsula abierta.

ZARCILLO.-Organo filiforme, contorneado en espiral, que sirve para sostenimiento de la planta: pepino. 


\section{USO DE LA CLAVE.}

La presente Clave analítica sirve para determinar las familias á las que pertenecen las plantas que nacen en la exhuberante flora mexicana, siguiendo la serie de respuestas sugeridas por los caracteres de una planta, á las preguntas formuladas al lado de cada número sucesivo. Aclararé esto por medio de algunos ejemplos prácticos: $10^{\circ}$ Sea el primero el café-Coffea arabica:A la pregunta núm. 1 hallo la respuesta que es una planta cuyas flores tienen androceo y gineceo reunidos, lo que me lleva al núm. 2 ; esto me conduce al núm. 3 porque el número de sus estambres no pasa de 10; aqui observo mi flor y noto que tiene 5 estambres, lo que me transporta al núm. 63 , el que me sugiere la respuesta de ovario infero, respuesta que á su vez me conduce al núm. 127; la respuesta de estambres libres que este número contiene me traslada al núm. 130 donde encuentro que el ovario de mi flor es pluri-locular, lo que á su vez me remite al núm. 135; como las flores de mi planta no están envueltas por espatas, paso inmediatamente al núm. 136 donde encuentro la respuesta de hojas opuestas sugerida por la planta en cuestión. El resultado de esta última observación que es el núm. 137 resuelve finalmente el problema, pues la respuesta de estipulas interfoliares que esta pregunta encierra me indica que la Coffea arabica es una planta que pertenece á la familia de las Rubiáceas.

2.0 El frijol-Phaseolus spec.-me suministrará el segundo ejemplo: A la pregunta núm. 1 encuentro la respuesta que es una planta de flores bisexuales, la que me conduce al núm. 2; esto me lleva al núm. 3 porque el número de sus estambres no pasa de 10; después de haber observado que las flores de mi planta tienen 
10 estambres, paso al núm. 215 que encierra la respuesta de ovario súpero; esto me traslada al núm. 216 que me remite á su vez al núm. 217 por tener la planta de que se trata flores de cdliz y corola; el 217 me transporta al núm. 249 pues tiene ésta flores de corola irregular. El ovario 1--locular de las flores de mi planta me conduce al núm. 251 que resuelve la cuestión, por lo que sé que el frijol es una Papilionácea.

3. ${ }^{\circ}$ El tercero y último ejemplo será el maiz--Zea mays:

A la pregunta núm. 1 hallo la respuesta que es una planta de flores diclinas, lo que me transporta al núm. 311; merced á la observación averiguo que es una planta monoica, pues hay flores de dos clases en el mismo individuo, lo que me remite al núm. 312 ; la respuesta de yerba ó sub-arbusto que éste contiene me conduce al 313 donde veo que es una planta con hojas; esto me traslada al núm. 315 cuya respuesta de planta terrestre, sugerida por ella misma, me lleva al núm. 323. Bien seguro que mi planta tiene hojas alternas, proposición encerrada en este ùltimo número, paso al 324 donde observo que las hojas del maiz son además envainadoras, por cuya razón siguiendo el número sugerido por esta respuesta, examino el núm. 325 en el que averiguo que el Zea mays es una Graminea.

Advertencia. Siempre que en el curso de la Clave se encuentre un paréntesis indica que el carácrer contenido en él no se hace extensivo á toda una familia, sino simplemente $\mathfrak{a}$ algunos géneros $\delta$ especies de la mismav 


\section{CLAVE ANALITICA DE LAS FAMILIAS.}

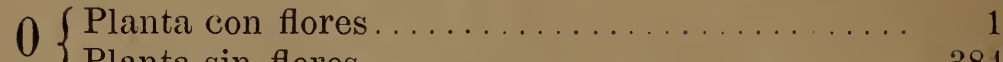

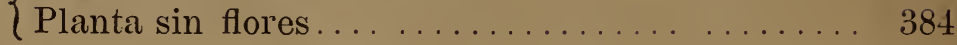

Flores todas, ó algunas por

$1\left\{\begin{array}{l}\text { lo menos, con androceo y } \\ \text { gineceo }\end{array}\right.$

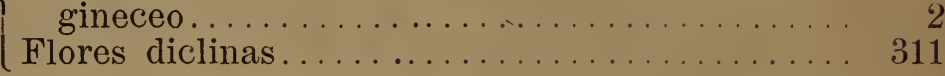

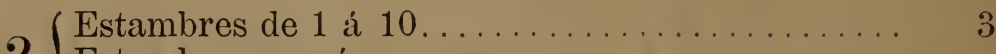

$2\{$ Estambres en número superior á $10 \ldots \ldots \ldots \ldots \ldots \ldots \ldots \ldots \ldots \ldots \ldots \ldots$

(Estambres de 1 á $3 \ldots \ldots \ldots \ldots \ldots \ldots \ldots \ldots$

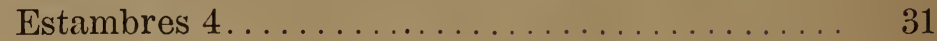

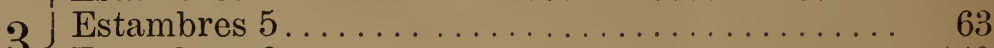

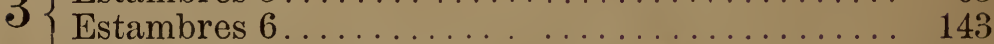

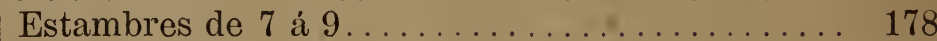

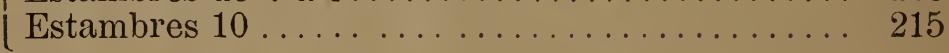

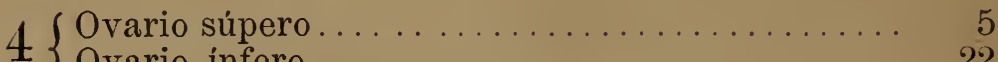

$4\left\{\begin{array}{l}\text { Ovario infero } \ldots \ldots \ldots \ldots \ldots \ldots \ldots \ldots \ldots \ldots \ldots, 22 \\ 2\end{array}\right.$

$5\{$ Perianto de cáliz y corola................ 6

$5\{$ Perigonio ó flor desnuda................. 14

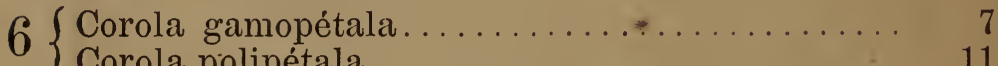

$\{$ Corola polipétala...................... 11

(Corola regular; árbol ó ar-

$7\left\{\begin{array}{l}\text { busto; cáliz gamosépalo; } \\ \text { estigma bilobado......... JAZMinÁcEAs. }\end{array}\right.$

Corola irregular......................... 8 
(Ovario de 4 carpelos sepa-

8 rados y un estilo en la cavidad central[terminado por un estigma bífido]....... LABIADAS.

Ovario único.

$9\left\{\begin{array}{c}\text { Ovario }(2-) \text { 4-locular; baya } \\ \text { ó drupa.............. Verbenáceas. }\end{array}\right.$

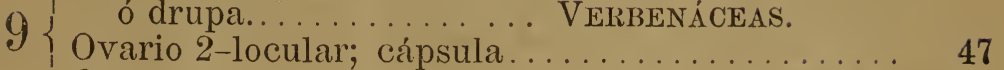

I Ovario 1-locular....................... 10

$10\left\{\begin{array}{l}\text { Planta acuática ó pantanosa; } \\ \text { flores espolonadas........ LENTIBULARIÁcEAS. }\end{array}\right.$

$10\{$ Planta terrestre, herbácea ó sub-frutescente; flores sin espolón.

Gesneriáceas.

11 Hojas compuestas......... Rutáceas.

$11\{$ Hojas sencillas; árbol ó arbolillo............................... 12

$12\left\{\begin{array}{l}\text { Hojas alternas; flores con } 1-2 \\ \text { estambres fértiles........ TEREBIN'TÁcEAs. }\end{array}\right.$

Hojas opuestas ó verticiladas . . . . . . . . . . . . .

(Hojas coriáccas sin estípulas; corola regular; 3 estambres andróforos; semi-

13 llas sin alas........... Hipocraté́ceas.

Hojas lampinas estipuladas; corola irregular; 3 estambres, 2 de ellos estériles; semillas de 1 sola ala.... VoquisıácEAs.

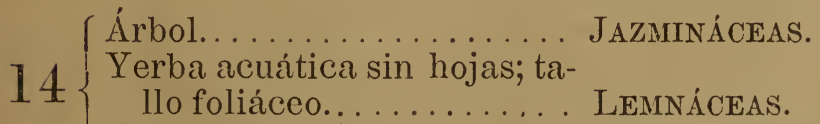
Yerba con hojas..................... 15

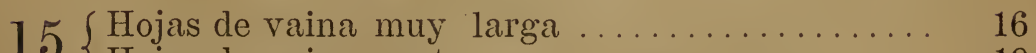

$\{$ Hojas de vaina corta.................. 19 
( Planta acuática, sumergida

16 ó flotante.

$\{$ Planta generalmente terrestre, nunca sumergida ni flotante.

17 Perianto nulo............ NAYADÁCEAS.

\{ Perigonio de seis divisiones. Pontederiáceas.

Cada flor entre 2 páleas; vai-

18 nas hendidas.......... Gramíneas.

Cada flor detrás de 1 pálea; vainas enteras......... CIPERÁcEAs.

$19\{$ Hojas estipuladas.

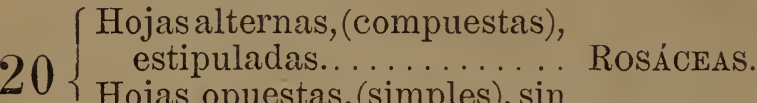

Hojas opuestas, (simples), sin estípulas.............. CARIOFILÁcEas.

$21\left\{\begin{array}{l}\text { Filos del perigonio membra- } \\ \text { nosos ó coloreados........ AMARANTÁcEAs. }\end{array}\right.$

Filos del perigonio herbáceos $\mathrm{y}$ verdes.

QUENOPODIÁCEAS.

$22\{$ Flores regulares..................... 23

$22\{$ Flores irregulares $\ldots \ldots \ldots \ldots \ldots \ldots \ldots \ldots \ldots \ldots \ldots \quad 26$

(Hojas radicales; estambres 3; ovario 3-locular con un estilo y un estigma 3-lo$23\left\{\begin{array}{l}\text { bado; planta herbácea.... . Burmaniáceas. } \\ \text { Hojas opuestas; estambres } 2 ;\end{array}\right.$ árbol ó árbusto siempre verde............... Columeliáceas.

Hojas alternas................... 24

(Estambres 2, (algunas veces

241 petalóideo); cáliz y coro-

$24\{$ la; hojas reticuladas....

Estambres 3; perigonio; ho-

( jas nervifoliadas. 
( Perigonio desprovisto de pelos; estambres opuestos á

25 las divisiones exteriores de éste............. Iridíceas.

Perigonio provisto de pelos; estambres opuestos á las divisiones interiores de és-

te. .................. HeModoráceas.

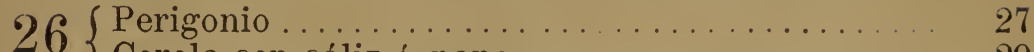

\{ Corola con cáliz ó papo................. 29

$27\{$ Estambres 3 fértiles....... IRIDÁCEAS.

\{ Estambres 1-2 fértíles.................. 28

$28\left\{\begin{array}{l}\text { dices petalóideos dentro } \\ \text { del perigonio........... Amomíceas. }\end{array}\right.$

Ovario 1-locular; un ginos-

I tema dentro del perigonio. ORQUIDÁCEAS.

Corola y papo; yerbas; flo-

29 res en racimos ó cimas terminales............ VALERIANÁCEAS

Corola y cáliz.

Corola gamopélata quinti

30 lobulada.............. GESNERIÁcEAs.

Corola polipétala; estambres $1-2 \ldots \ldots \ldots \ldots \ldots$ Onagráceas.

$31\left\{\begin{array}{l}\text { Ovario súpero } \ldots \ldots \ldots \ldots \ldots \ldots \ldots \ldots \ldots \ldots \\ \text { Ovario } \ldots \ldots \ldots\end{array}\right.$

$\{$ Ovario ínfero ó semi-ínfero .............. 57

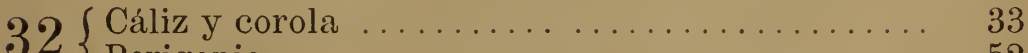

$\{$ Perigonio ......................... 52

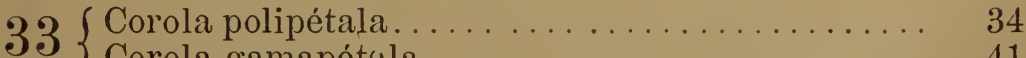

\{Corola gamapétala................... 41

(Pistilos libres; hojas herbáceas; arbusto......... Celastráceas.

$34\{$ Pistilos soldados ó estigmas sesiles; pétalos y estambres hipoginos ó casi hiI poginos.......................... 35 


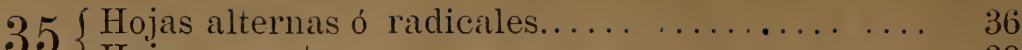

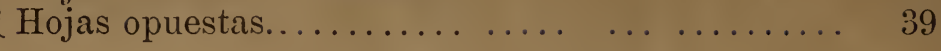

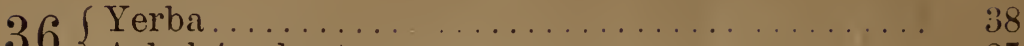

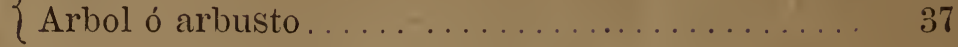

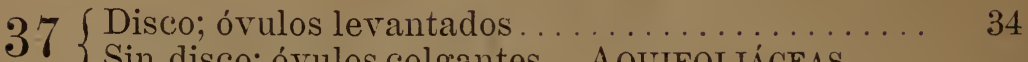
\{ Sin disco; óvulos colgantes.. AQUifoliácEAs.

Sépalos 4, acompañados de 2 bracteillas; hojas radica-

$38\{$ les...................

Sépalos 2 (caducos); hojas al-

ternas.. ............ PAPAVERÁCEAS.

BERBERÍDEAS.

Uno ó pocos órulos colgantes; fruto carnoso que contiene de 2--6 núculos hue-

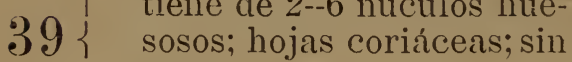

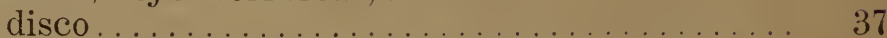

Uno ó pocos óvulos lerantados.

Estambres opuestos á los pe-

40 talos; fruto carnoso; (disCo).............. RAMNÁCEAS.

Estambres alternos con los pétalos; fruto seco; (disco) Celastráceas.

(Corola regular; estambres

41 Corola más ó menos irregu-

lar; [estambres desiguales]

(Arbol ó arbolilio de hojas

$42\left\{\begin{array}{c}\text { coriáceas ............... } \\ \text { Yerba ó planta sub-frutes- }\end{array}\right.$ cente.

$43\left\{\begin{array}{l}\text { Corola tierna coloreada.... Gexcianáceas. } \\ \text { Corola membranosa desco- } \\ \text { lorida; (inflorescencia en } \\ \text { forma de espiga)........ Plantagíneas. }\end{array}\right.$ 
$\$ 4$ Planta sin hojas, (escamas en su lugar)............. OrobáNQueas.

Plarta con hojas.................... 45

45 Ovario 4-locular, (de 4 carpelos distintos $) \ldots \ldots \ldots \ldots \ldots \ldots \ldots \ldots \ldots \ldots$

Ovario $1-2-$ locular . . . . . . . . . . . . . 47

( Carpelos separados; estilo

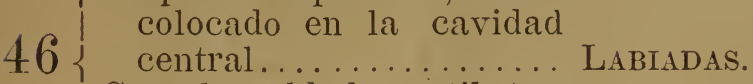

Carpelos soldados; estilo ter-

I minal.............. VERBENÁCEAS.

$47\{$ Estigma bilobado ó bífido .............. 48

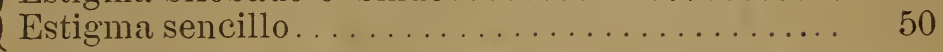

$48\{$ Fruto, cápsula..................... 51

$\{$ Fruto, baya, drupa ó aquenio . . . . . . . . . . 49

(Fruto, baya ó drupa...... Verbenáceas.

Fruto, aquenio; estigma de

49 dos divisones cortas y desiguales; disco hipogino unilateral; flores en capítulos; cáliz persistente; yerba ......................

Globulariáceas.

( Estigma cóncavo en su centro; cápsula que se abre en

$50\left\{\begin{array}{l}\text { dos valvas; yerba, rara } \\ \text { vez planta sub-frutescente }\end{array}\right.$ Estigma oblícuo y unilateral; baya ó drupa............

( Cápsula que se abre por agujeros, ó placas irregulares, ó por 2 ó 4 ralvas de dehiscencia loculicida

Có septífraga ..............

ESCROFULARIÁCEAS. ticidad en 2 ralvas loculi-

Cápsula que se a a . . . . . . . .

ACANTÁCEAS. vas paralelas ó transversales al tabique; (semillas aladas; árbol ó arbolillo) BIGNONIÁcEAs. 
$52\left\{\begin{array}{l}\text { Yerba ó planta su-frutescen- } \\ \text { te }\end{array}\right.$

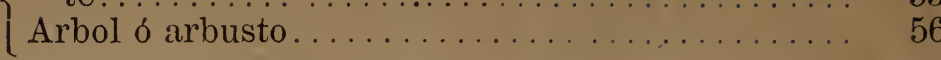

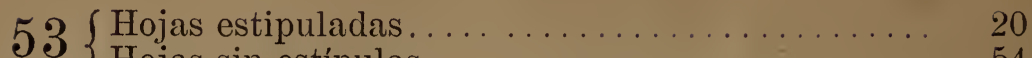

$\{$ Hojas sin estípulas................... 54

$54\left\{\begin{array}{l}\text { Planta acuática sumergida ó } \\ \text { flotante; flores en espigas. NAYADÁCEAS. }\end{array}\right.$

Planta terrestre....................... 55

$55\left\{\begin{array}{l}\text { Perigonio coroliforme; } \\ \text { lucro muchas veces cali- } \\ \text { ciforme }] \ldots \ldots \ldots \ldots \ldots \ldots\end{array}\right.$

Perigonio membranoso ó her-

báceo....

Ovario uni-locular; anteras

$56\left\{\begin{array}{c}\text { que se abren mediante } \\ \text { válvulas;plantaaromática LAURÁCEAS. } \\ \text { Ovario pluri-locular. .... RAMNÁCEAS. }\end{array}\right.$

$57\left\{\begin{array}{l}\text { Ovario semi-ínfero; yerba ó } \\ \text { Orariosillo }\end{array}\right.$

Ovario completamenteínfero

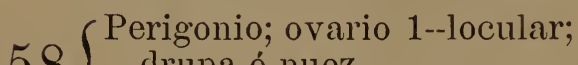

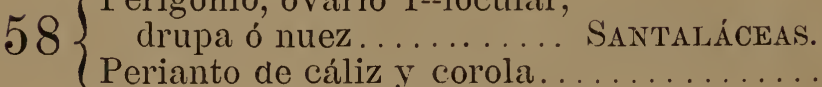

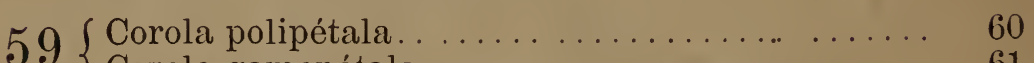

$60\left\{\begin{array}{l}\text { Estambres desiguales; baya } \\ \text { ó cápsula............... ONAGRÁcEAs. } \\ \text { Estambres iguales; drupa.. CORNÁCEAS. }\end{array}\right.$

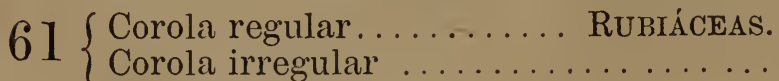

Estambres iguales; flores en

capítulos, estando cada

62 una envuelta por un involucro propio........... DIPSÁcEAS.

Estambres didinamos; flores axilares ó terminales.... GESNERIÁcEas. 
$63\{$ Ovario súpero ........................... 64

$\{$ Ovario infero ó semi-infero ............... 127

$64\{$ Cáliz y corola ....................... 65

$\left\{\begin{array}{l}\text { Perigonio } \ldots \ldots \ldots \ldots \ldots \ldots \ldots \ldots \ldots \ldots \ldots \ldots \ldots \ldots \ldots \ldots \ldots \\ \end{array}\right.$

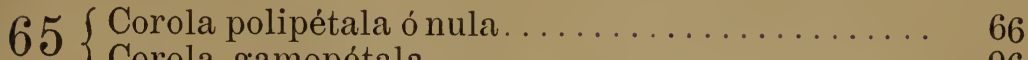

\{corola gamopétala....................... 96

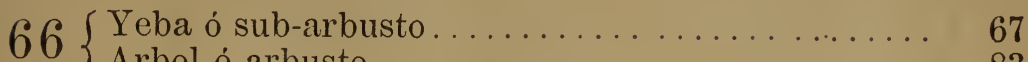

$\{$ Arbol ó arbusto ..................... 83

$67\{$ Cáliz evidentemente gamo-

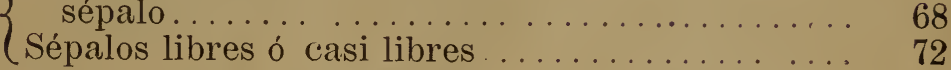

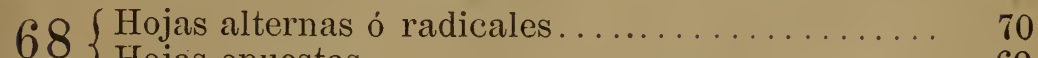

$\{$ Hojas opuestas....................... 69

(Hojas sin estípulas; inser-

69 ción hipogínica......... CaRIOFILÁceas.

Hojasestipulas; inserciónperigínica................ Paroniquíceas.

70 Hojas estipuladas; estambres

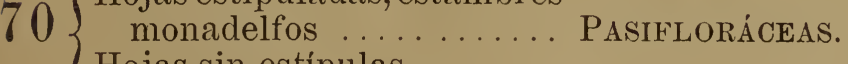

Hojas sin estípulas

Corola gamopétala con estambres hipoginos, ó co-

71 rola polipétala con estambres epiginos........... Plumbagíneas.

Estambres insertos en el tubo calicinal........... Turneráceas.

$72\left\{\begin{array}{l}\text { Pistilos líbres.. } \ldots \ldots \ldots \ldots \ldots \ldots \ldots \ldots \ldots \ldots \ldots \ldots \ldots \ldots \\ \text { Pistilos } \ldots \ldots \ldots \ldots \ldots\end{array}\right.$

$\{$ Pistilos soldados .................... . 77

$73\{$ Hojas estipuladas. . . . . . . . . . . . . . . . 74

$\{$ Hojas sin estípulas................. 75

$74\{$ Hojas alternas........... RosácEAs.

$\{$ Hojas opuestas . . . . . . . . Paroniquí́ceas.

$75\{$ Pistilos numerosos......... Ranunculáceas.

$\{$ Pistilos $2-5 \ldots \ldots \ldots \ldots \ldots \ldots \ldots \ldots \ldots \ldots \ldots \ldots \ldots$ 
$76\left\{\begin{array}{l}\text { Planta carnosa; pistilos } 5 . . . \text { Crasuliceas. } \\ \text { Planta herbácea; hojas radi- } \\ \text { cales ó alternas; yerba } \\ \text { pantanosa.............. Droseráceas. }\end{array}\right.$

$77\{$ Flores regulares. . . . . . . . . . . . . . . 78

$\{$ Flores irregulares . . . . . . . . . . . . . . 81

$78\{$ Tres [á 5$]$ placentas parietales.................. 76

$\{$ Placenta central ó axilar................. 79

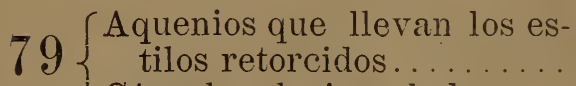

$\{$ tilos retorcidos..........

Cápsula pluri-ovulada................... 80

$80\{$ Planta suculenta y carnosa. Portulacíceas.

$80\{$ Planta herbácea; tallo nudoso y articulado....................... 69

Hojas sin estípulas; estam-

$81\left\{\begin{array}{l}\text { bres sinantéreos; cápsula } \\ \text { que se abre con elastici- }\end{array}\right.$ dad................ BALSAMINÁcEAS.

Hojas estipuladas..................... 82

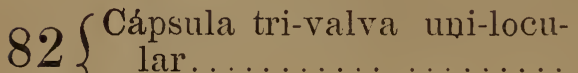

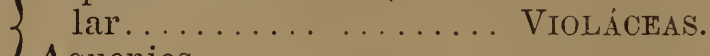

Aquenios . . . . . . . . . . . . . . . . $\quad 79$

Hojas muy pequeñas, esca-

$83\left\{\begin{array}{l}\text { miformes; ovario triangu- } \\ \text { lar, uni--locular; árbol ó }\end{array}\right.$

arbolillo; cápsula........ TAMARICÁCEAS.

(Hojas comunes....................... 84

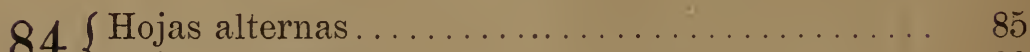

$\{$ Hojas opuestas .................... $\quad 90$

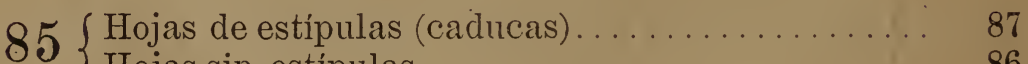

$\{$ Hojas sin estípulas ................... 86

$86\left\{\begin{array}{l}\text { Planta con disco anular.... Terebintáceas. } \\ \text { Planta }\end{array}\right.$

\{lanta sin disco.......... AquifoliácEas.

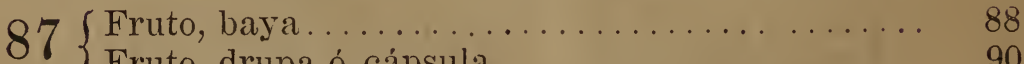

$\{$ Fruto, drupa ó cápsula ............... 90 
$88\left\{\begin{array}{c}\text { Estambres libres; ovario bi- } \\ \text { locular; (arbusto ó arbolillo } \\ \text { voluble, sarmentoso, pro- } \\ \text { visto de zarcillos opuestos }\end{array}\right.$ á las hojas)... . ....... AHrelindíceas.

Estambres monadelfos.

Ovario 1-locular; (árbol con tallo cesprovisto de zarci-

$89\{$ llos, ó arbusto sarmentoso

con zarcillos).......... PASIFLOR íteEAS.

Ovario 5-locular; [árbol ó ar-

bolillo]............. BüTTNERIÁCEAS.

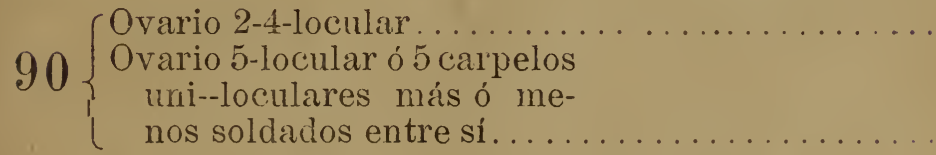

91 Estambres Kbres.......... RúTícEas.

Estambres monadelfos.

$92\left\{\begin{array}{l}\text { Sépalos provistos de glándu- } \\ \text { las en su base; árbol ó ar- } \\ \text { bolillo sarmensoso y tre- } \\ \text { pador }\end{array}\right.$

$92\{$ bolillo sarmensoso y tre-

pador ....................
Sépalos desprovistos de glán-

184

93 Planta con disco hipogino

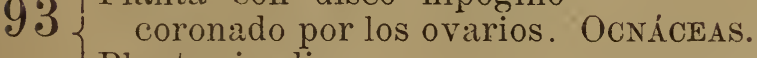

Planta sin disco.

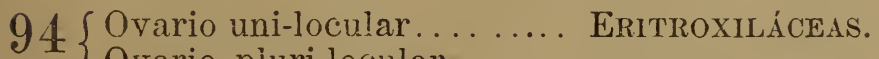

Ovario pluri-locular................. 89

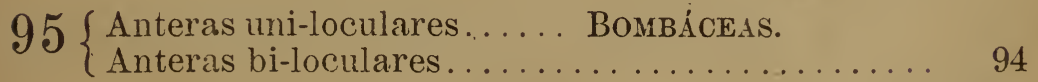

$\{$ Ovario 1-locular..................... 97

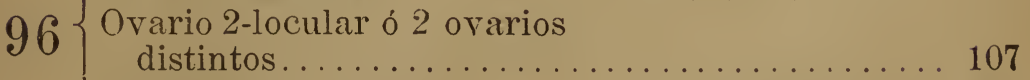

Lovario $3-6$-locular.... ..................... 114

$97 \int$ Estambres hipoginos........ Plumbagíneas

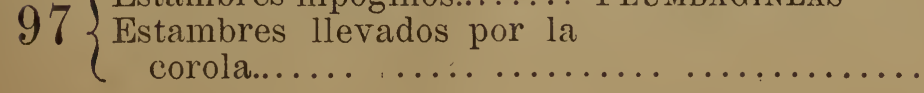




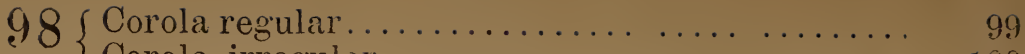

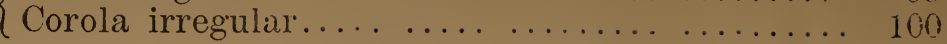

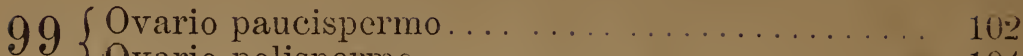

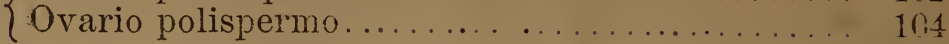

100 Flores en capitulos rodea-

dos de brácteas........... Giobulatrácen.s.

Inflorescencia distinta....................... 101

Covario paucispermo; 4 estambres didinamos y 1 estéril, ó 5 estambres igua-

$101\{$ les y 3 estériles; árbol ó arbusto............... BigNoniácEAS.

Ovario polispermo; 5 estanbres iguales y fértiles; yerba, arbusto ó árbol...... Solanáceas.

Uno ó pocos óvulos colgantes; hojas coriáceas.................... 86

Cuatro ó más óvulos, enla$102\left\{\begin{array}{l}\text { zados dos á dos en otras } \\ \text { tantas placentas salientes }\end{array}\right.$ en forma de semi-tabiques. HIDRofilácEas.

Uno ó pocos óvulos levanta-

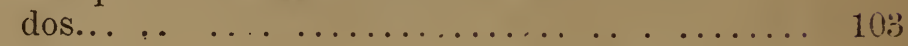

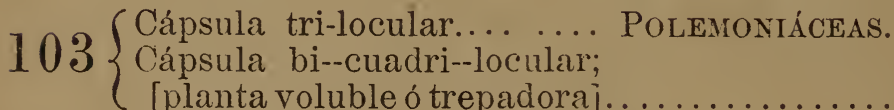

[planta voluble ó trepadoraj................ 105

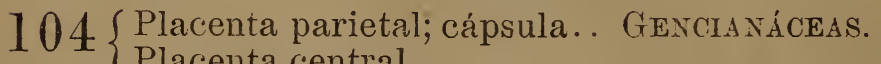

$\{$ Placenta central ....................... 106

$105\left\{\begin{array}{l}\text { Planta parásita sin hojas y } \\ \text { sin clorófila................ Cuscutáceas. }\end{array}\right.$

(Planta voluble con hojas... . Convolvuláceas.

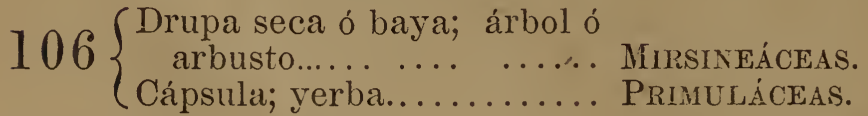

$107\{$ Corola irregular......................... 98

$\{$ Corola regular....................... 108

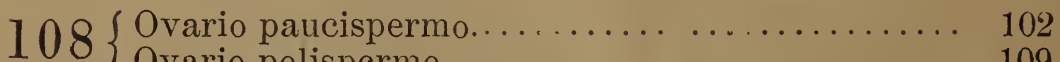

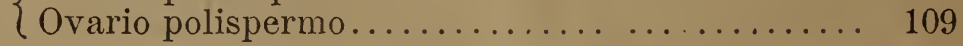


$\left\{\begin{array}{c}\text { Hojas opuestas, verticiladas } \\ \text { ó nulas }\end{array}\right.$

$110\{$ Cápsula ó baya; placenta

$110\left\{\begin{array}{l}\text { central gruesa; lóculos } \\ \text { oblicuos }\end{array}\right.$

Cápsula; lóculos rectos.... Hidroleáceas.

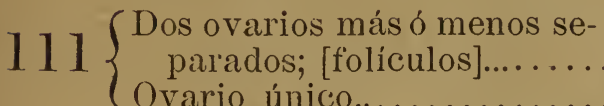

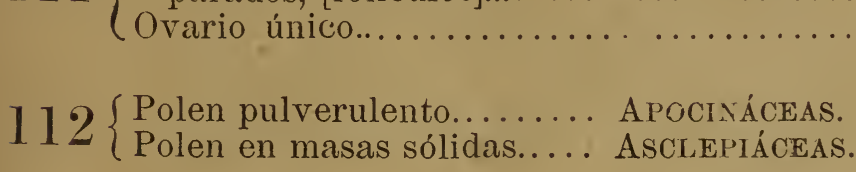

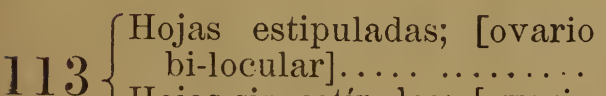
Hojas sin estipulas; [ovario

uni-locular $] . \ldots \ldots \ldots \ldots \ldots \ldots \ldots, \ldots \ldots \ldots, 104$

$\left\{\begin{array}{l}\text { Cuatro ovarios monosper- } \\ \text { mos separados; fruto, } 4 \text { nú- }\end{array}\right.$

$114\{$ culos; [planta cubierta de pelos muy bastos]....... BORragináceas.

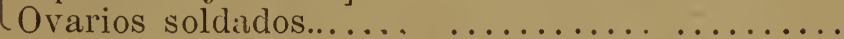

Uno ó dos óvulos en los ló-

$115\left\{\begin{array}{l}\text { culos del ovario, [ó } 4 \text { óvu- } \\ \text { los en un ovario uni-locu- }\end{array}\right.$ lar, ó un lóculo monosper-

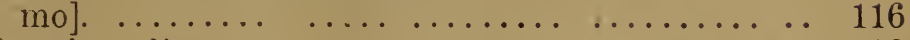

Ovario polispermo.................... 118

$116\{$ Yerba ó sub-arbusto..................... 103

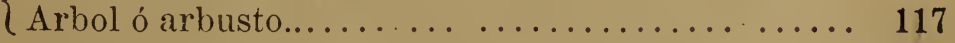

Disco; drupa carnosa; ovario de 4 ú 8 lóculos monos-

117 permos, rara vez uni-locular................. CORdíceeas.

Sin disco; drupa carnosa; ovario de 2-6 lóculos monospermos............ AqUILOfol.tíceas. 
(Anteras que se abren por

$118\left\{\begin{array}{c}\text { dos poros en el ápice.... } \\ \text { Anteras de dehiscencia dis- }\end{array}\right.$ tinta; planta herbácea ó subfrutescente.

Cápsula ó baya; placenta

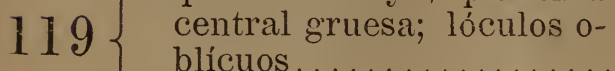

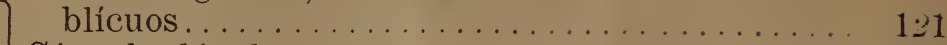

Cápsula; lóculos rectos.................. 120

$120\left\{\begin{array}{r}\text { Cáliz de } 5 \text { divisiones profun- } \\ \text { das y persistentes; (hojas }\end{array}\right.$

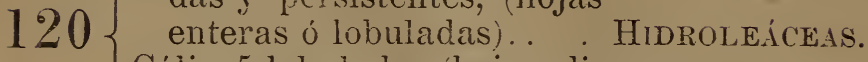

Cáliz 5-lobulado; (hojas di-

vididas y pinnatífidas.... POLEnONIÁCEAS.

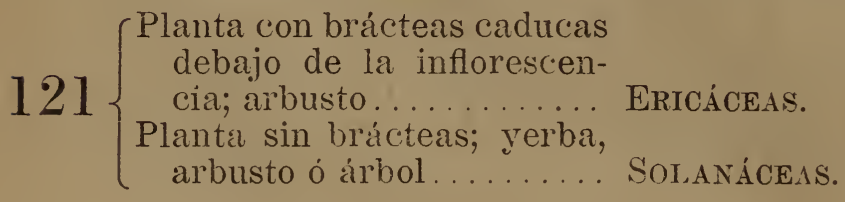

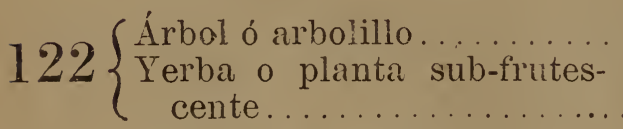

$129\{$ Hojas sin estipulas; (brácteas

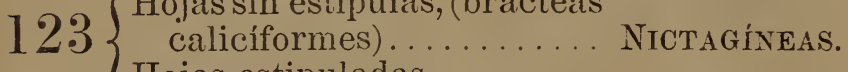

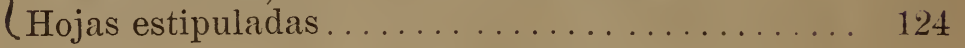

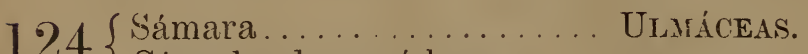

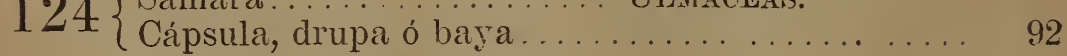

$125\{$ Hojas provistas de vainas

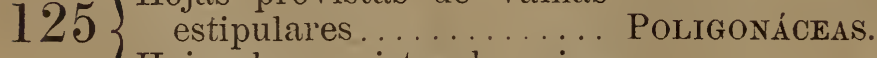

(Hojas desprovistas de vainas ........... 126

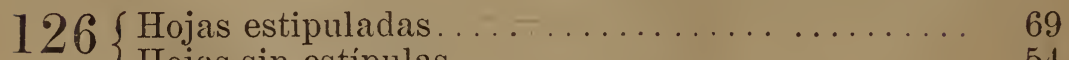

$\{$ Hojas $\sin$ estípulas.................. 54

$127\left\{\begin{array}{l}\text { Estambres soldados } \ldots \ldots \ldots \ldots \ldots \ldots \ldots \ldots \ldots \\ \text { Estan } \ldots \ldots \ldots \ldots\end{array}\right.$

$\{$ Estambres libres..................... 130

$128\left\{\begin{array}{l}\text { Ovario pluri-locular polis- } \\ \text { permo .................. LobeliácEas. }\end{array}\right.$

Ovario uni-locular monospermo; flores en capítulos. 
$129\left\{\begin{array}{l}\text { Estambres sinantéreos; es- } \\ \text { tigmas bífidos.......... SinantÉreas. } \\ \text { Estambres sinantéreos y mo- } \\ \text { nadelfos; estigma sencillo; } \\ \text { planta herbácea......... CALICERÁCEAS. }\end{array}\right.$

$130\{$ Ovario uni-locular...................... 131

$\{$ Ovario pluri-locular................... 135

131 Perigonio; drupa ó nuez.... Santaláceas.

$\{$ Cáliz y corola ........................... 132

$132\{$ Fruto, baya.............................. 134

$\{$ Fruto, aquenio ó cápsula................... 133

$133\{$ Inflorescencia distinta; flores axilares ó radicales.. Prinuláceas.

$134\left\{\begin{array}{l}\text { Corola gamopétala ......... CAPRIFolí́CEAS. } \\ \text { Corola polipétala......... RiBESIÁCEAS. }\end{array}\right.$

Muchas flores reunidas en
espatas; grandes plantas

135 herbáceas; ovario 3-locular.................. Musáceas.

Inflorescencia distinta ................. 136

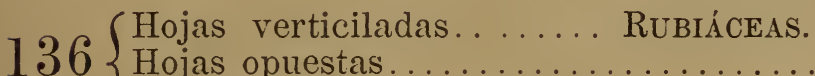

Hojas alternas ....................... 139

$137\left\{\begin{array}{r}\text { Hojas provistas de estípulas } \\ \text { interfoliares................. }\end{array}\right.$

(Hojas desprovistas de estipulas ............. 138

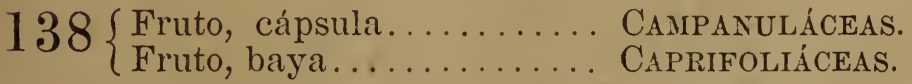

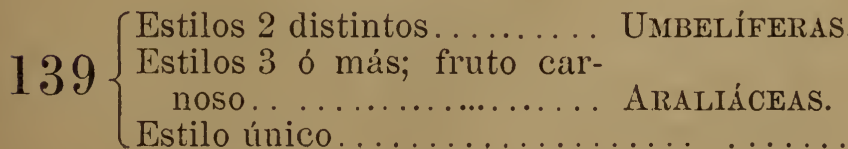


$140\{$ Corola gamopétala; verba,

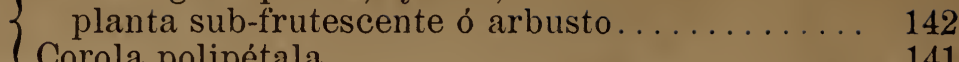

Corola polipétala.................... 141

Planta herbácea ó árbol; flores pequeñas en umbelas; estambres alternos con los

$141\{$ Árbol ó arbusto; flores axila-

Araliáceas.

res, solitarias ó glomeruladas, algunas veces capitulos ó racimos; pétalos unguiculados; estambres o-

puestos á los pétalos..... RAMNÁCEAS.

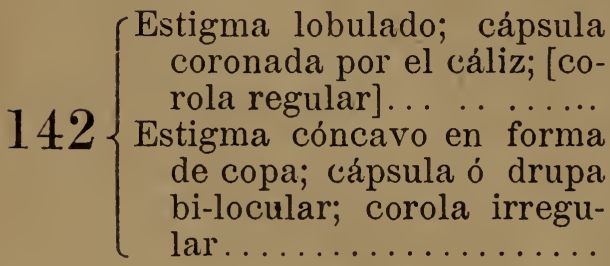

Campanulíceas.

$143\{$ Ovario súpero $\ldots \ldots \ldots \ldots \ldots \ldots \ldots \ldots \ldots \ldots \ldots \ldots \ldots \ldots \ldots \ldots$

$\{$ Ovario ínfero ó semi-infero............... 172

Cáliz y corola ......................... 146

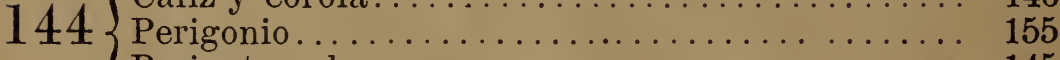

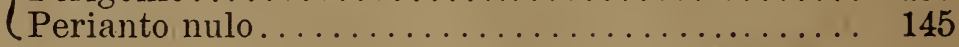

(Dos glumas; espiguillas unifloras; 2 estilos con estigmas plumosos: cariópside

GRAmíneas.

145 Una escama en lugar del perianto; planta anual á orilla de las aguas ó flotante; 3-4 pistilos uni-loculares; cápsulas indehiscentes mono-dispermas. . .......... SAURURÁCEAS.

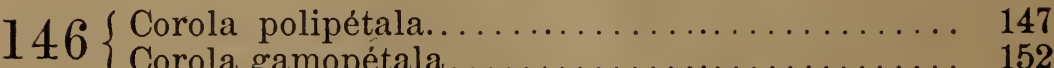

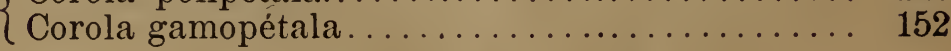


Pistilos distintos ó estigma

$147\left\{\begin{array}{l}\text { profundamente bilobado } \\ \text { Pistilos soldados; yerba, sub- }\end{array}\right.$

arbusto ó arbusto:

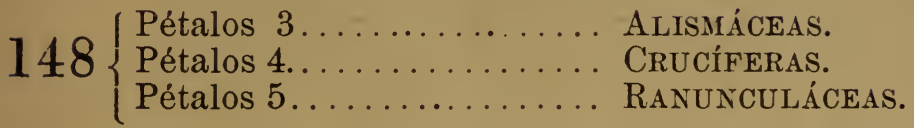

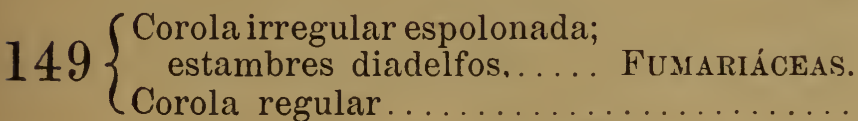

Cáliz prolongadamente gamosépalo; estambres peri-

150 ginos; hojas sin estípulas. LitráceAs.

Cáliz polisépalo ó apenas gamosépalo ..

$151\{$ Estambres tetradinamos.... Crucíferas.

151 Estambres iguales; cáliz coloreado; yerba ó arbolillo BERBERÍDEAS.

$152\left\{\begin{array}{l}\text { Yerba .................... Gencianáceas. } \\ \text { Ápol ó arbolillo; cáliz gamo- }\end{array}\right.$ sépalo; hojas alternas.................. 153

$153\{$ Cáliz polisépalo; (disco hipo-

gino).............. TernstremiáCEAS

Cáliz gamosépalo

[Ovario 6 ó 12 locular; lóculos monospermos; óvulos pendientes; estambres todos fértiles; estilo dividido; (madera dura y negra en su centro)............. Ebenácenas.

$154\{$ Ovario uni-ó pluri-locular; un óvulo levantado (ó pendiente) en cada lóculo; estambres interiores fértiles, los exteriores petaloídeos; hojas muy enteras; estilo I entero; jugo lechoso...... SAPotáceas. 
$154\left\{\begin{array}{l}\text { Ovario 4-locular; } 4 \text { óvulos } \\ \text { axilares en cada lóculo, } \\ \text { dos levantados y dos cai- } \\ \text { dos; fruto ligeramente car- } \\ \text { noso con 1-4 núculos hue- } \\ \text { sosos más ó menos irregu- } \\ \text { lares................. EsTIRACÁcEas. }\end{array}\right.$

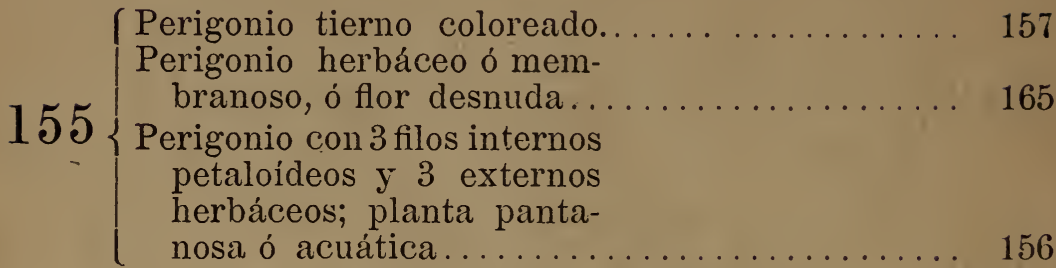

$156\left\{\begin{array}{l}\text { Varios carpelos; estambres } \\ \text { de } 6 \text { - } 30 \ldots \ldots \ldots \ldots \ldots \ldots \text { ALISMáceas. } \\ \text { Un ovario; estambres } 3 \text { fér- } \\ \text { tiles y } 3 \text { estériles........ XIRIDÁceas. }\end{array}\right.$

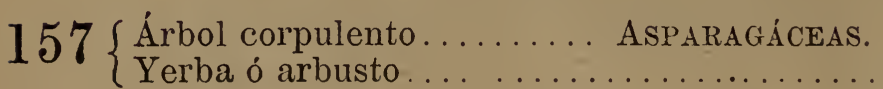

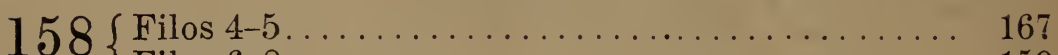

$\left\{\begin{array}{l}\text { Filos } 6-8 \ldots \ldots \ldots \ldots \ldots \ldots \ldots \ldots \ldots \ldots \ldots \ldots \ldots \ldots \ldots \\ 159\end{array}\right.$

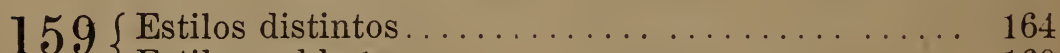

$\{$ Estilos soldados ..................... 160

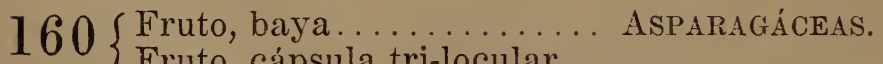

$\{$ Fruto, cápsula tri-locular .... . . . . . . . . . 161

(Filos todos coloreados.................... 163

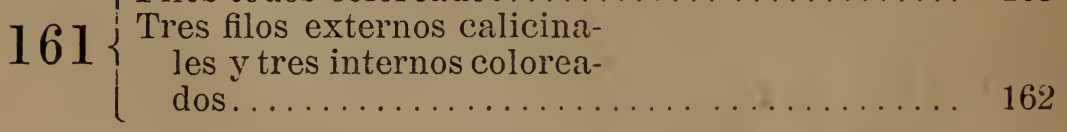

$162\left\{\begin{array}{l}\text { Hojas estrechas y rígidas; } \\ \text { tres estigmas; (parásita). TILANDsIáceas. } \\ \text { Hojas herbáceas; un estig- }\end{array}\right.$

Hojas herbáceas; un estig-

ma................. CoMelináceas. 
Estigma tri-lobado; planta

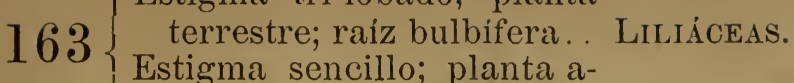

Estigma sencillo; planta acuática; raíz fibrosa...... PONTEDERIÁceas.

Ovario uni-locular monospermo.............. Poligonáceas

Ovario tri-locular ó 3 ova-

164 rios polispermos; anteras introrsas............. Colquicáceas.

Ovario 3-6-locular; $(3 \quad 06$ ovarios;) uno ó dos óvulos

en cada lóculo.......... Juncagíneas.

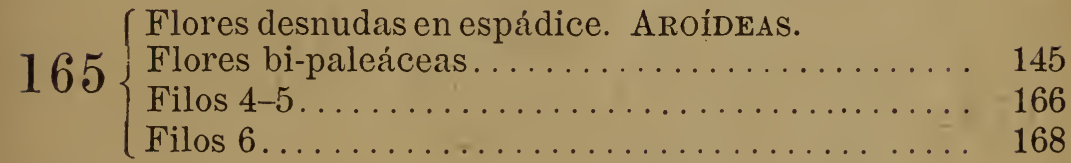

$166\{$ Flores en espádice envuelto por una espata......................... 165

(Inflorescencia distinta.................. 167

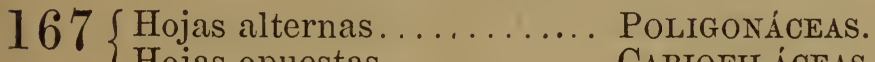

$\{$ Hojas opuestas . . . . . . . CARIOFILÁCEAS.

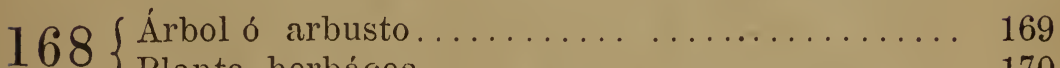

$\{$ Planta herbácea..................... 170

$169\left\{\begin{array}{c}\text { Tallo, estípite; planta mo- } \\ \text { nocotiledónea.......... Palmeras. } \\ \text { Tallo, rizoma ó tronco; plan- } \\ \text { ta dicotiledónea......... Poligonáceas. }\end{array}\right.$

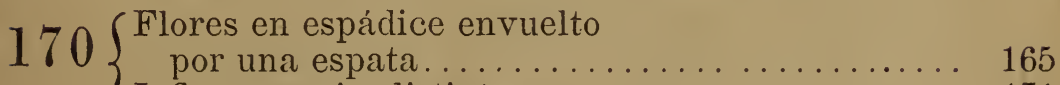

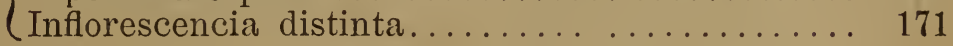

(Flores en espigas; planta pantanosa; 3 ó 6 ovarios separados............ JunCagineas.

171 Flores en panículas ó cimas encerradas antes de abrirse en la vaina de la última hoja; ovario súpero, 3-1ocular, polispermo....... JUNCÁCEAS. 
$171\left\{\begin{array}{l}\text { Flores en fascículos y dis- } \\ \text { puestas en racimos; ova- } \\ \text { rio súpero monosperma; }\end{array}\right.$

$171\{$ rio súpero monospermo; hojas provistas de vainas estipulares........................... 164

$172\{$ Cáliz y corola ......................... 173

$\left\{\begin{array}{l}\text { Perigonio. } \ldots \ldots \ldots \ldots \ldots \ldots \ldots \ldots \ldots \ldots \ldots \ldots \ldots \ldots \ldots \ldots \ldots \\ 175\end{array}\right.$

$173\left\{\begin{array}{c}\text { Arbusto parásito de hojas } \\ \text { coriáceas y persistentes; }\end{array}\right.$

fruto, baya monosperma. LORANTÁcEAS.

Planta no parásita.

(Hojas verticiladas ú opuestas, con estípulas; baya. . RUBIÁcEAs.

$174\{$ Hojas alternas sin estípulas; árbol ó arbolillo; fruto I carnoso............... Estiracíceas.

$175\left\{\begin{array}{c}\text { Perigonio de } 3 \text { divisiones, } \\ \text { irregular; hojas alternas; } \\ \text { estambres ginandros... }\end{array}\right.$

estambres ginandros..... ARISTOLOQUIÁCE $\Lambda$ S.

Perigonio de 6 divisiones.

176

( Los 3 filos exteriores del pe-

$176\left\{\begin{array}{l}\text { rigonio más ó menos cali- } \\ \text { cinales; hojas alternas, dis- } \\ \text { puestas en haces en la ba- }\end{array}\right.$ puestas en haces en la base del tallo............ Bromeliáceas.

Los 6 filos del perigonio co-

I loreados...

$177\left\{\begin{array}{l}\text { Perigonio provisto exterior- } \\ \text { mente de pelos. ........ HEMODORÁCEAS. } \\ \text { Perigonio desprovisto de pe- }\end{array}\right.$

Perigonio desprovisto de pelos...................... AMARILIDÁcEAS.

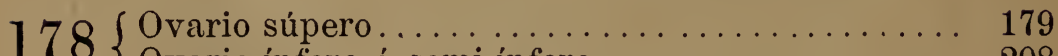

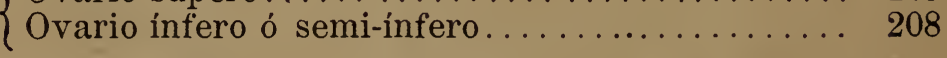

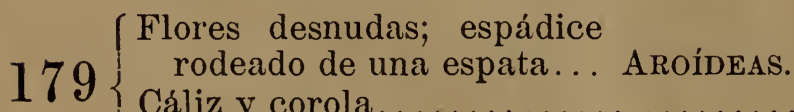

Cáliz y corola ............................ . 180

Perigonio............................ 201 


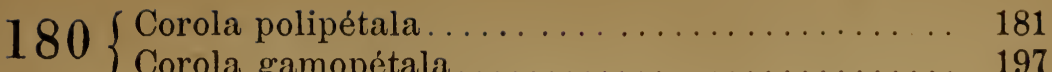

\{ Corola gamopétala .................. 197

$181\left\{\begin{array}{l}\text { Estilos más ó menos distin- } \\ \text { tos. . } \ldots \ldots \ldots \ldots \ldots \ldots \ldots \ldots \ldots \ldots \ldots \ldots \ldots\end{array}\right.$

(Estilos soldados.................. 187

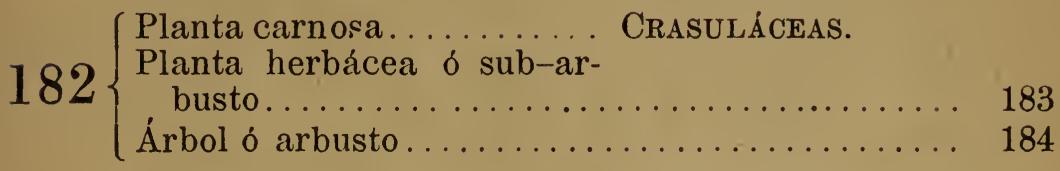

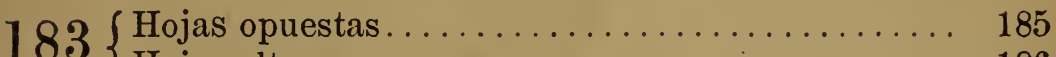

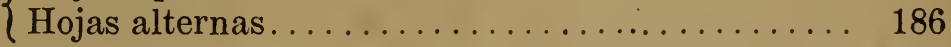

$\left\{\begin{array}{c}\text { Glándulas en la base de los } \\ \text { sépalos; (hojas con estípu- }\end{array}\right.$

$184\{$ las)............... Malpighiáceas. -

Sépalos sin glándulas; hojas

I sin estípulas......... TEREBintácEas.

$185\left\{\begin{array}{l}\text { Óvulos numerosos en una } \\ \text { placenta central.......... Cariofiláceas. }\end{array}\right.$

$185\{$ Dos óvulos en cada lóculo; 5 estambres fértiles y 5 es-

tériles............. LinácEAS.

(Aquenios monospermos ó folículos polispermos; sépalos caducos........... RANUNCULÁcEAS.

186 Cápsula polisperma ó baya; sépalos persistentes; 10 estambres.............. Oxalideas.

Fruto suculento; flores en espiga............. Fitolacáceas.

$187\{$ Arbol ó arbusto.................. 188

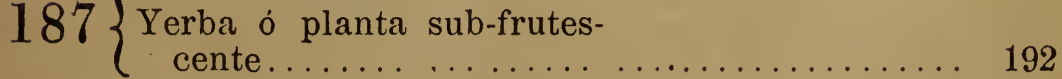

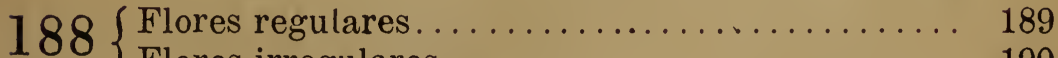

$\{$ Flores irregulares. . . . . . . . . . . . . 190

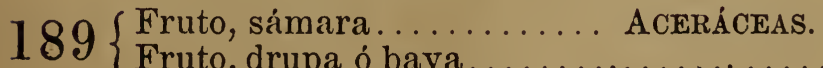

$\{$ Fruto, drupa ó baya.................... 191 
$190\left\{\begin{array}{c}\text { Hojas alternas, (impari-pin- } \\ \text { nadas)......................... SAPINDÁceAs. } \\ \text { Hojas opuestas, digitadas... }\end{array}\right.$

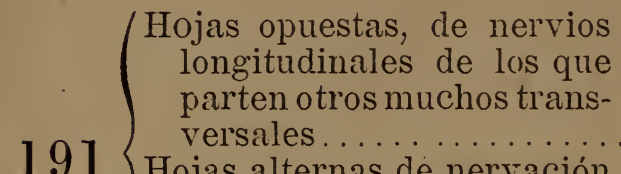

común; estambres 8 ; ovario 4-locular; drupa monosperma................ Olacáceeas.

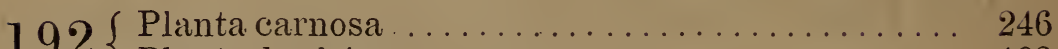

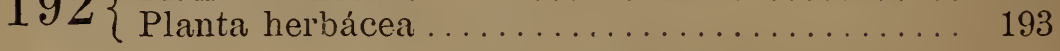

Cáliz espolonado y colorea-

$193\{$ do; yerba trepadora; hojas

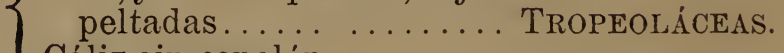

(Cáliz sin espolón.......................... 194

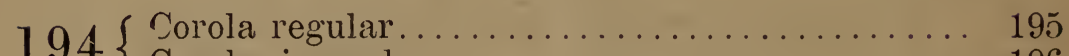

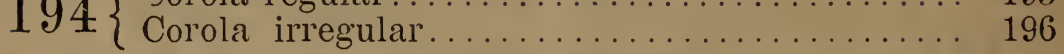

$195\left\{\begin{array}{l}\text { Hojas de nervios longitudi- } \\ \text { nales de los que parten } \\ \text { otros muchos transversa- } \\ \text { les y paralelos }\end{array}\right.$

Hojas de nervación común;

(planta aromática)...... Rutáceas.

$196\left\{\begin{array}{c}\text { Hojas sencillas: dos de los } \\ \text { sépalos petalóideos; (es- } \\ \text { tambres andróforos...... Poligaluíceas. } \\ \text { Hojas compuestas (impari- } \\ \text { pinnadas............... SAPINdíce.s. }\end{array}\right.$

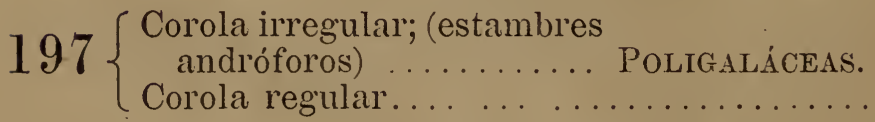

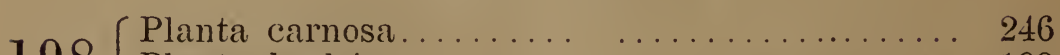

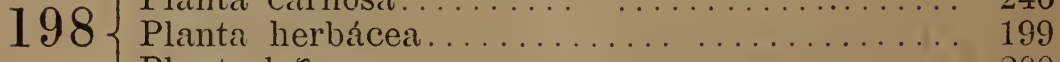

Planta leñosa........................ 200 
$199\{$ Estilos 4 -5 ; estambres $10 \ldots$ Oxalideas.

$\{$ Estilo único ó nulo........ Gencianácesas.

$200\left\{\begin{array}{l}\text { Muchos óvulos axilares; ba- } \\ \text { ya ó cápsula............ ERICÁcEAs. }\end{array}\right.$

Lóculos mono-paucispermos................ 153

$201\{$ Perigonio herbáceo....................... 202

$\{$ Perigonio coloreado...................... 204

$202\{$ Estambres periginos.................... 74

$\{$ Estambres hipoginos................... 203

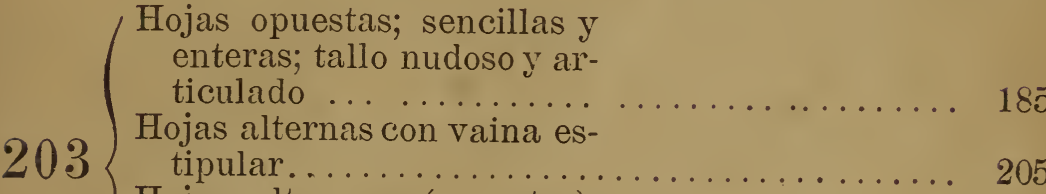

Hojas alternas, (opuestas), sin estípulas, coriáceas; árbol ó arbolillo; baya ó drupa carnosa........................ 207

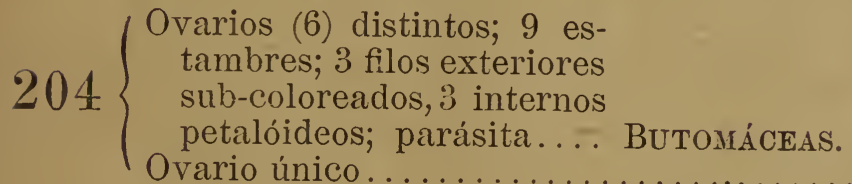

$205\{$ Hojas envainadoras. ...... PoligovícEas.

$\{$ Hojas $\sin$ vainas........................ 206

$206\left\{\begin{array}{l}\text { Estambres periginos; (peri- } \\ \text { gonio } 4 \text {-fido)........... TMIELEÁCEAS. }\end{array}\right.$

Estambres hipoginos.................... 207

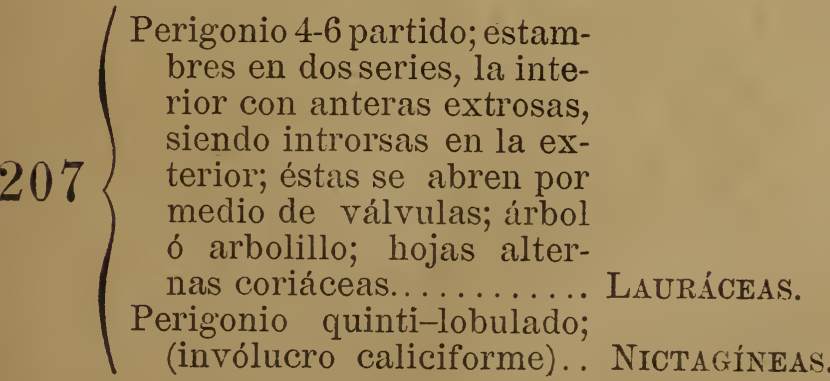


$208\left\{\begin{array}{l}\text { Yerba ó planta sub-frutes- } \\ \text { cente } \ldots \ldots \ldots \ldots \ldots \ldots \ldots \ldots \ldots \ldots \ldots \ldots \ldots \ldots \ldots \ldots \ldots \ldots \ldots \ldots \ldots \ldots\end{array}\right.$

YHojas de nervios longitudi-

209 nales y trasversales; coro-

la polipétala........................ 214

(Hojas de nervación común................ 210

(Fruto abayado ó drupáceo. VACCiní́cE.ts.

Fruto, cápsula coronada por

$210\{$ los dos estilos.......... SAXIFragíates.

Fruto coriáceo; hojas sim-

( ples; árbol ó arbolillo................... 211

\Hojas de estipulas interfoliares................. Rrzoforíce.ts.

Hojas sin estípulas; [flores

211 apétalas $] . . . . \ldots \ldots \ldots . . . . .$. CoMbretácens.

Hojas de estipulas caducas; 8 estambres, 4 de ellos estériles; ovario bi-locular con dos estilos; 4 pétalos. HaManelidíceas.

$212\{$ Planta carnosa...................... 246

$\{$ Planta herbácea ó leñosa.................. 213

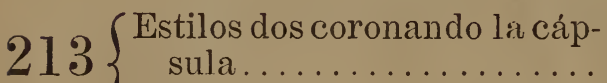

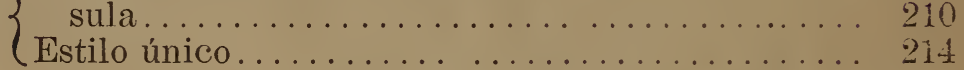

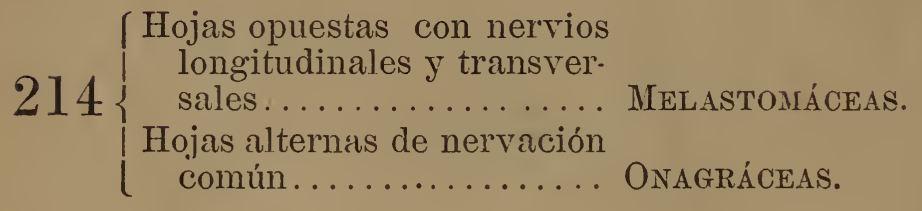

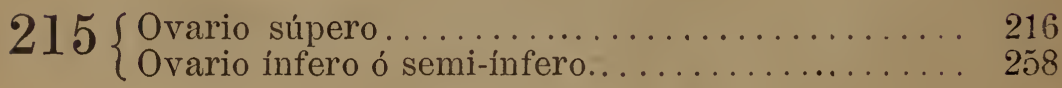

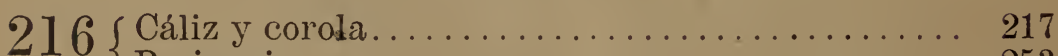

$\{$ Perigonio.......................... 253 
$217\left\{\begin{array}{l}\text { Corola regular } \\ \text { Corola irregular }\end{array}\right.$

$218\left\{\begin{array}{l}\text { Corola polipétala. } \\ \text { Corola gamopétala }\end{array}\right.$

$219\{$ Estilos libres

$220\{$ Hojas sin estipulas.

$221\{$ Hojas alternas. . . . . . . . . . . . . . . . . . . 222

Hojas opuestas.

$222\{$ Estambres libres.

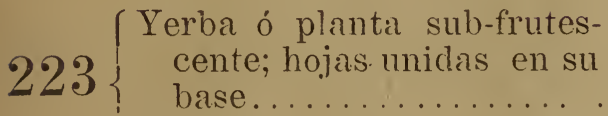

Arbol ó arbusto ........................ 225

$224\{$ Orario pluri-locular.................... 92

$\{$ Ovario uni-locular....................... 226

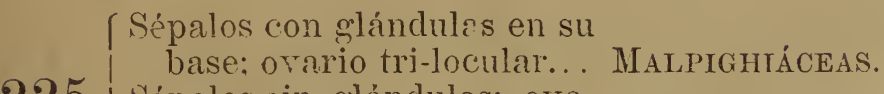

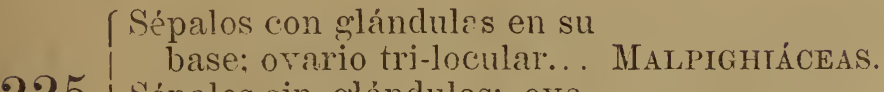

225 Sćpalos sin glándulas; ovario uni-locular monosper-

I mo................ Eritroxilácens.

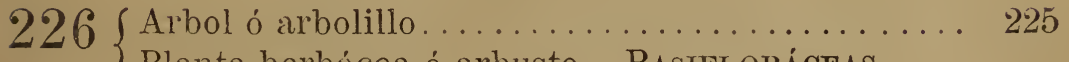
Planta herbácea ó arbusto.. PAsIfloráceas. 
Hojas pinnadas, sin estípu-

229 las; estambres monadel-fos; árboles ó arbolillos...

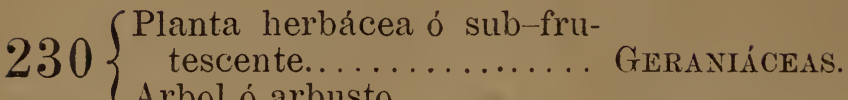

Arbol ó arbusto

(Sépalos con glánciulas en su

$231\{$ Sépalos sin glándulas; plan-

ta resinosa; estípulas caducas................. Rutácens.

23. $\begin{aligned} & \text { Fruto, cápsula polisperma; } \\ & \text { semillas aladas.......... CEDreláceas. }\end{aligned}$

$232\left\{\begin{array}{l}\text { sento, cápsula ó drupa dis- } \\ \text { Frute }\end{array}\right.$ perma; semillas sin alas.. MELIÁceas.

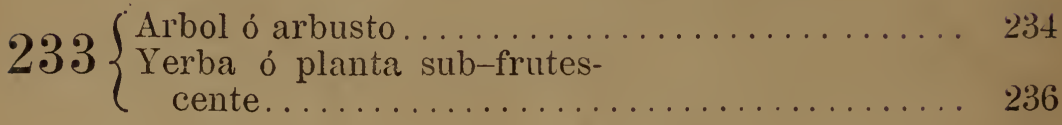

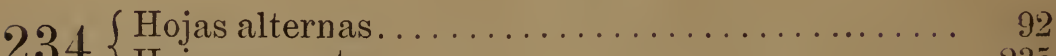

$235\left\{\begin{array}{l}\text { Hojas de nervación común; } \\ \text { estambres monadelfos.... ERITRoxilácEas. } \\ \text { Hojas con nervios longitudi- }\end{array}\right.$

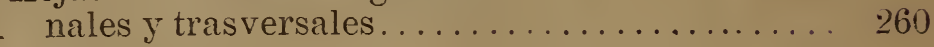

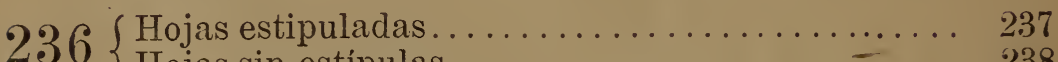

$\{$ Hojas $\sin$ estípulas........................ 238

$237\left\{\begin{array}{c}\text { Fruto, } 5 \text { aquenios que llevan } \\ \text { consigo el estilo que se re- }\end{array}\right.$

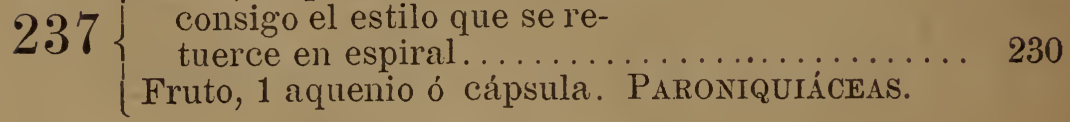

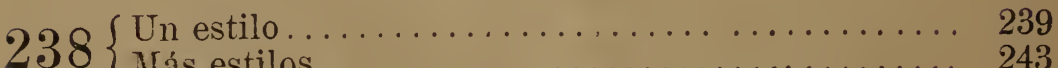

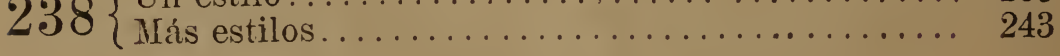




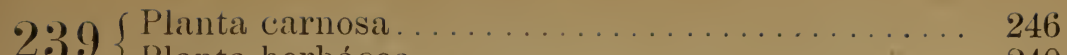

$\{$ Planta herbácea..................... 240

$240\{$ Hojas partidas . . . . . . . . . . . . . . . . . 231

$\{$ Hojas enteras....................... 241

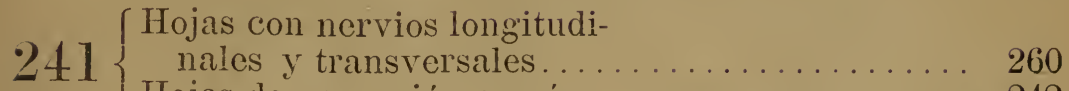

Hojas de nervación común. . . . . . . . . . . . 242

Y Hojas radicales con la lámina atenuada en pecíolo,

$242\{$ irritables al tacto; placenta pariental.......... DroserácEas.

Ilojas no irritables al tacto,

( coriáceas; placenta axilar Pinoláceas.

Hojas radicales con la lámina atenuada en pecíolo,

$243\left\{\begin{array}{r}\text { irritables al tacto......... } \\ \text { Hojas alternas ó glomerula- }\end{array}\right.$ das, cápsula coronada por los dos estilos.

$244\{$ Ýerba ó planta sub-fruticosa . . . . . . . . . . 245

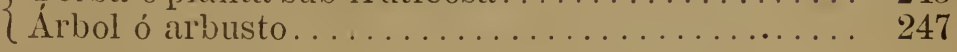

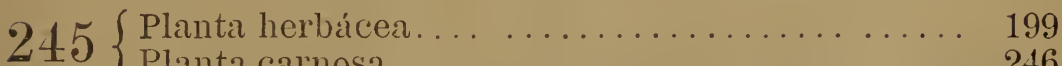

$\{$ Planta carnosa...................... 246

$246\{$ Pistilos distintos......... Crasuláceas.

$\{$ Pistilos soldados......... Portulacáceas.

Orario de 3-5 lóculos polispermos; placenta axilar; estigma bi-lobulado; cápsula ó baya........... ERICÁcEAs.

Orario 4-locular; 4 óvulos

$2+7$ axilares en cada lóculo, dos levantados y dos caídos; fruto ligeramente carnoso con 1- 4 núculos huesosos más ó menos irregulares............... EstTuRACÁceas. ( Lóculos monospermos . . . . . . . . . . . . . . 
(Estilo de 2-4 divisiones de las que cada una lleva un estigma capitulado...... Cordí́ceas.

248 Estilo terminado por un estigma sencillo ó lobulado; estambres interiores fértiles, siendo estériles los exteriores............ SAPOTÁcEAs.

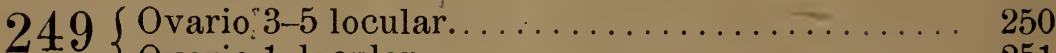

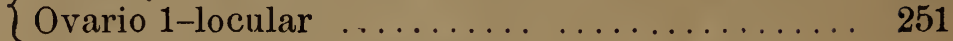

Estambres andróforos; ho-

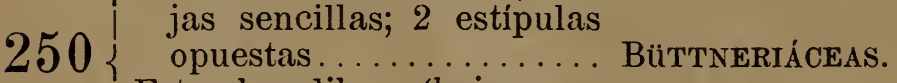

Estambres libres; (hojas com-

(puestas)............. SAPINDÁCEAS.

( Corola papilionácea; estam-

$251\left\{\begin{array}{l}\text { bres monadelfos ó diadel- } \\ \text { fos; óvulos uni-seriados; } \\ \text { legumbre............... }\end{array}\right.$

legumbre........... Papilionáceas.

Corola no papilionácea; [es-

(tambres libres].................... 252

(Árbol ó arbusto; óvulos uni-

seriados; legumbre....... CESALPINIÁCEAS.

252 Yerba ó planta sub-frutescente: óvulos pluri-seriados; cápsula.......... REsedáceas.

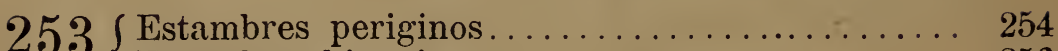

$\{$ Estambres hipoginos . . . . . . . . . . . . 256

$254\{$ Fruto, legumbre. . . . . . . . . . . . . . 252

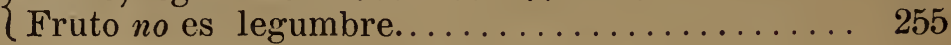

$255\{$ Hojas estipuladas....... RosíceAs.

\{ Hojas sin estípulas........ Paroniquiáceas.

$256\{$ Estambres monadelfos . . . . . . . . . . . . 92

$\{$ Estambres libres..................... 257

$\left\{\begin{array}{l}\text { Estilos } 3 \text {; glándulas en la ba- } \\ \text { se de los sépalos........ Malpighí́ceas. }\end{array}\right.$

257 Estilo trífido; sépalos sin

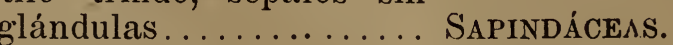

Estilos 5 ó menos ......... CARIOFILÁcens.

IEstilo único............. Nictagíneas. 


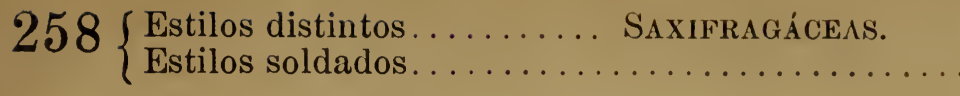

259

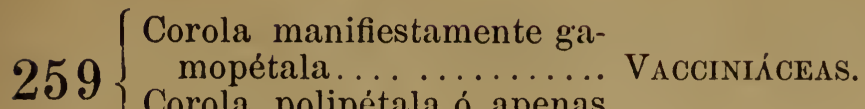

Corola polipétala ó apenas gamopétala....................... 266

$260\left\{\begin{array}{c}\text { Hojas con nervios longitudi- } \\ \text { nales y transversales..... Melastomíceas. } \\ \text { Hojas de nervación común; } \\ \text { planta carnosa............ Portulacáceas, }\end{array}\right.$

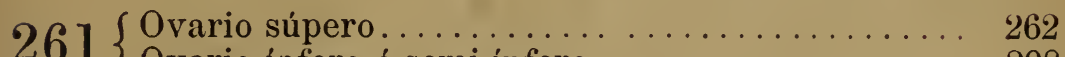

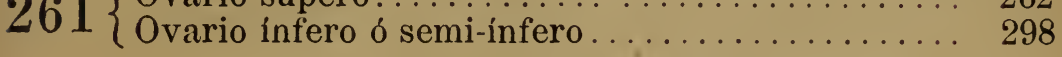

$262\{$ Estambres libres ó casi libres................ 263

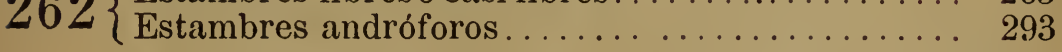

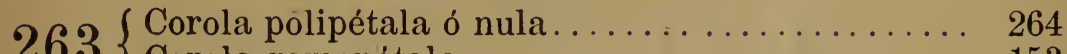

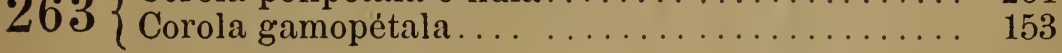

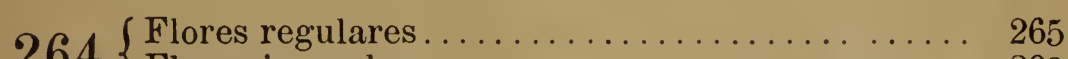

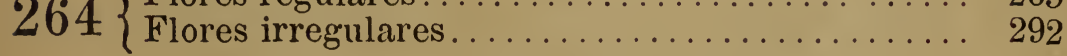

$265\{$ Estilos ó pistilos distintos................ 266

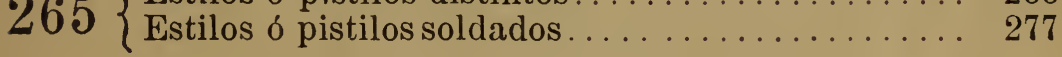

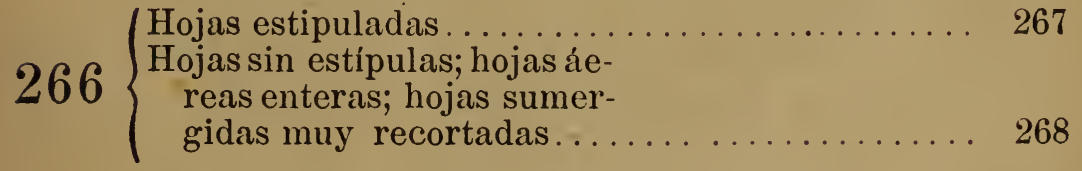

Estambres hipoginos; árbol

$267\left\{\begin{array}{c}\delta \text { arbolillo; hojas coriáceas } \\ \text { y persistentes........... MAGNOLIÁCEAS. }\end{array}\right.$

Estambres periginos . . . . . . . . . . . . . . . . 306

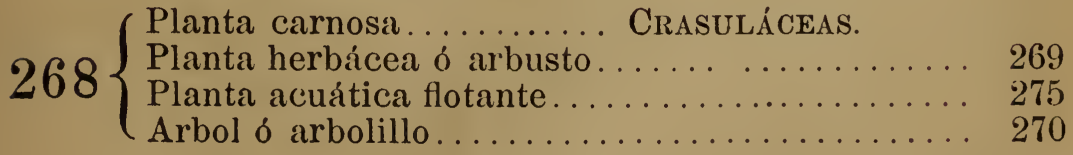

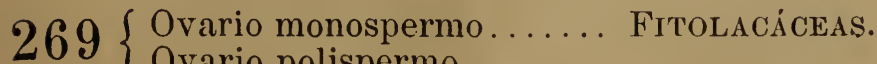

$\{$ Ovario polispermo. 
$270\left\{\begin{array}{l}\text { Perianto doble } \ldots \ldots \ldots \ldots \ldots \ldots \ldots \ldots \ldots \ldots \ldots \ldots \ldots \ldots \\ \text { Perignio } \ldots \ldots \ldots \ldots \ldots \ldots\end{array}\right.$

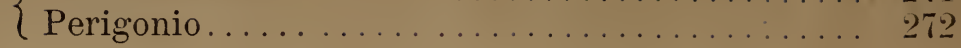

$271\left\{\begin{array}{l}\text { Sépalos } 3 ; 6 \text { pétalos dispues- } \\ \text { tos en dos series........... ANONáceAs. } \\ \text { Sépalos } 5 ; 5 \text { ó más pétolos. }\end{array}\right.$

(Sépalos $5 ; 5$ ó más pétalos ................ 974

Estigma de $3-10$ divisiones. Flacurtíceas.

$272\{$ Estigma sencillo; anteras que se abren mediante válvulas $\ldots \ldots \ldots \ldots \ldots$....... LuŔ́ceas.

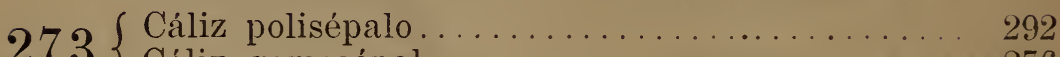

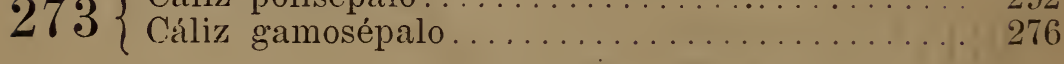

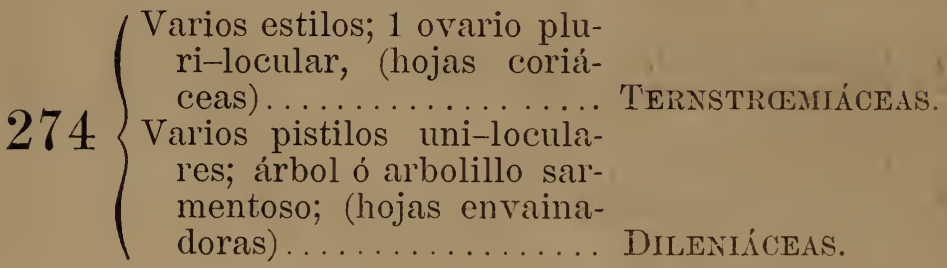

$275\left\{\begin{array}{l}\text { Un ovarjo pluri-locular co- } \\ \text { ronado por los estigmas.. NNFÉ́ceas. } \\ \text { Varios ovarios uni-carpela- } \\ \text { res y uni-loculares termi- } \\ \text { nados por un estilo senci- } \\ \text { llo................... CABOMBBícens. }\end{array}\right.$

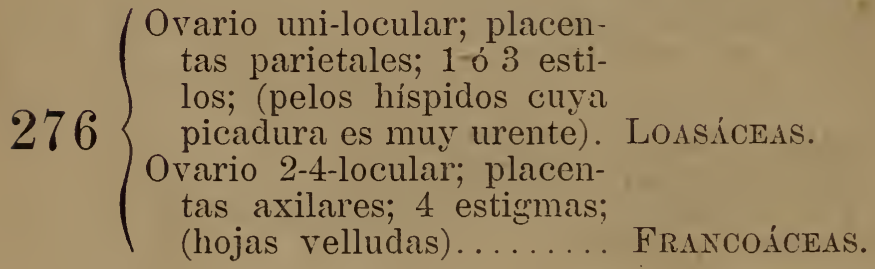

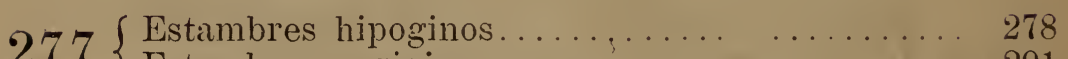

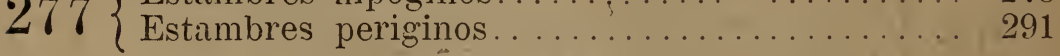

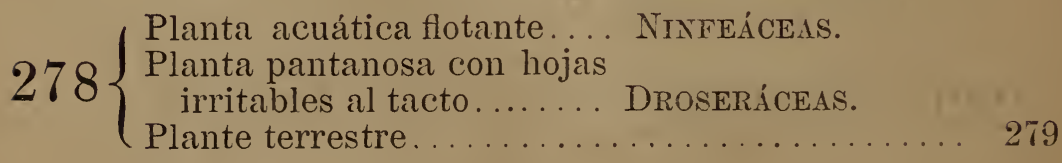


$279\{$ Hojas alter'nas. . . . . . . . . . . . . . . . 280

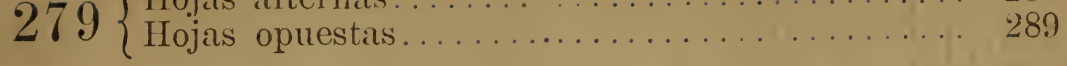

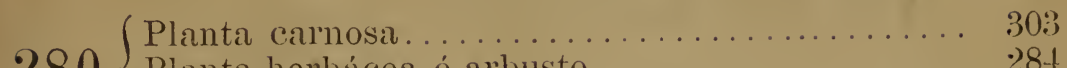

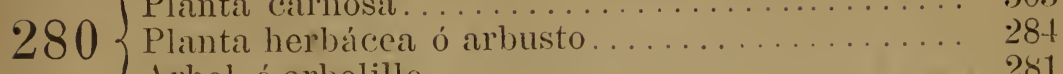

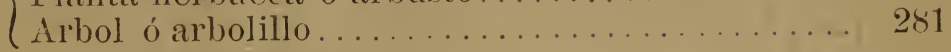

$281\{$ Hojas estipuladas..................... 283

$281\{$ Hojas sin estípulas . . . . . . . . . . . . . . 282

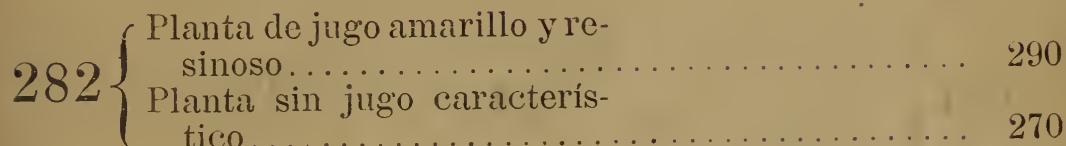
tico

$283\left\{\begin{array}{l}\text { Sépalos } 3-6 ; \text { de } 3-27 \text { pétalos; } \\ \text { (hojas coriáceas)........ Magnolííceas. } \\ \text { Sépalos 4-5; de } 4-5 \text { pétalos. TILIÁceas. }\end{array}\right.$

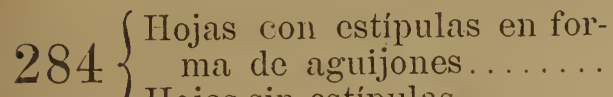

Hojas sin estípulas.

285

286

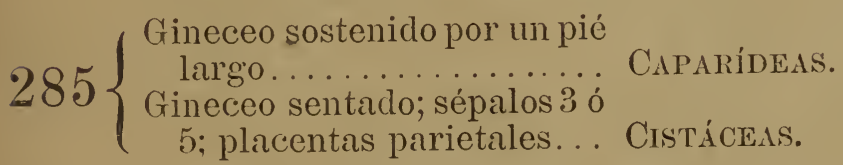

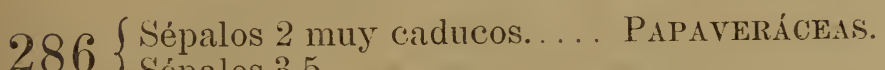

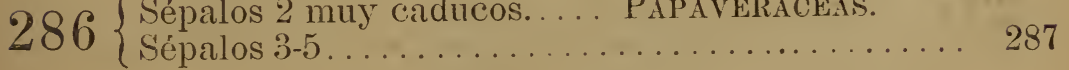

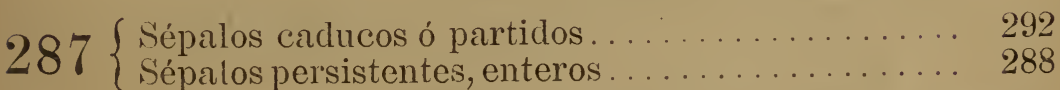

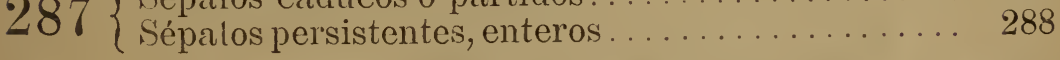

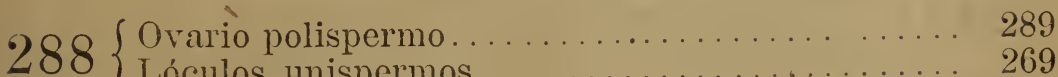

$288\{$ Lóculos unispermos.................... 269

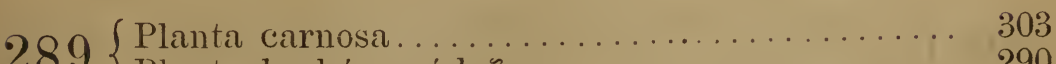

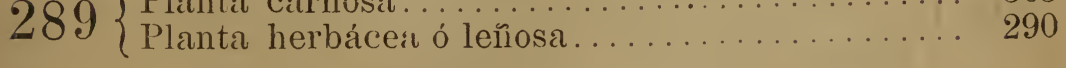

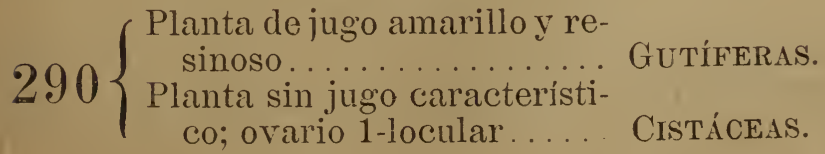




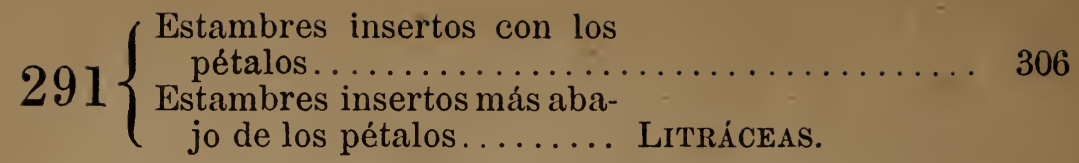

$292\left\{\begin{array}{l}\text { Un estilo en cada pistilo.... RANUNCULÁCEAS. } \\ \text { Tres estilos............. RESEDÁCEAS. }\end{array}\right.$

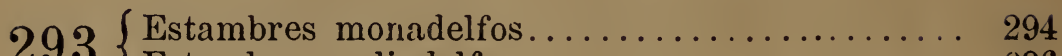

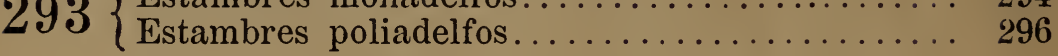

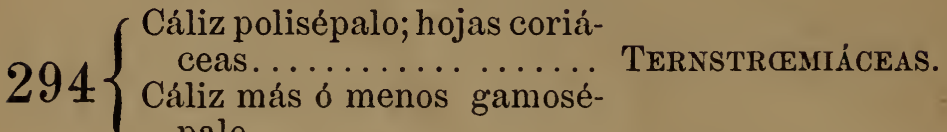
palo ............................ 295

$295\left\{\begin{array}{c}\text { Anteras uni-loculares; flores } \\ \text { regulares; (calículo) ..... MALvícEas. } \\ \text { Anteras bi-loculares; flores } \\ \text { irregulares............. BüTtNerí́cEAS. }\end{array}\right.$

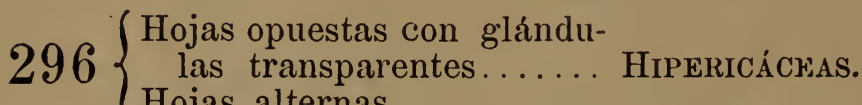

$\{$ Hojas alternas...................... 297

(Hojas estipuladas; estambres en 5 haces; varios estilos............... Bonbáceas.

297 Hojas sin estipulas, articuladas, provistas de glándulas vesiculosas; estilo grueso ............... Auranciáceas.

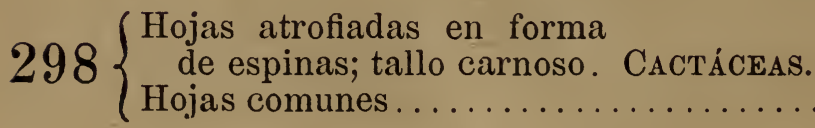
299

$299\left\{\begin{array}{l}\text { Planta herbácea ó frutes- } \\ \text { cente } \ldots \ldots \ldots \ldots \ldots \ldots \ldots \ldots \ldots \ldots \ldots \ldots \ldots \ldots \ldots \ldots \ldots \ldots \ldots \ldots \ldots \ldots\end{array}\right.$

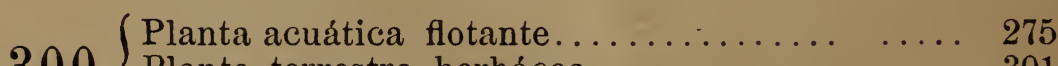

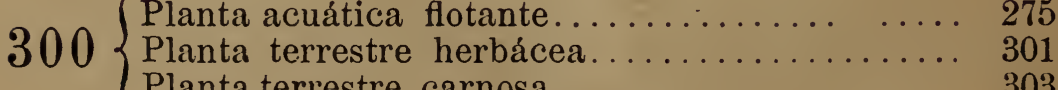

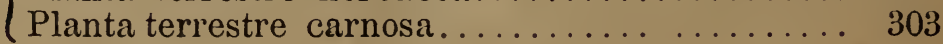




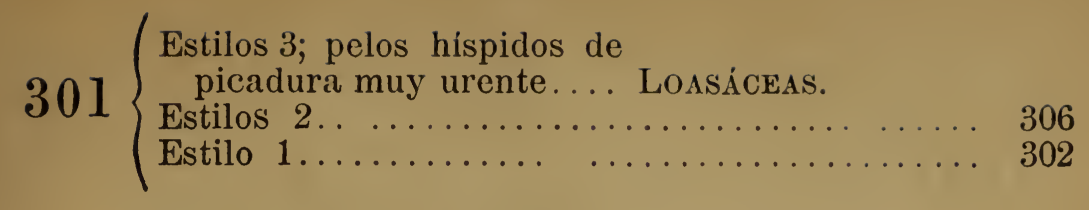

$302\{$ Cáliz y corola; planta pro-

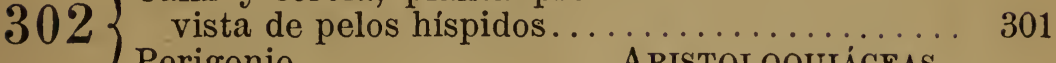

Perigonio................. ARISTOLOQUIÁCEAS.

$303\left\{\begin{array}{c}\text { Ovario uni-locular; un estilo; } \\ \text { (2 sépalos)............. Portulacáceas. } \\ \text { Ovario pluri-locular; varios } \\ \text { estilos; (cáliz de } 4 \text { ó más } \\ \text { lóbulos)................ MesembriantonáCEas. }\end{array}\right.$

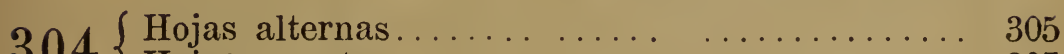

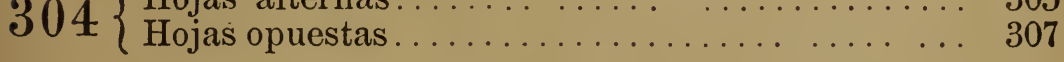

$305\left\{\begin{array}{l}\text { Hojas coriáceas con puntos } \\ \text { translúcidos................. MirTáceas. } \\ \text { Hojas de contextura y for- }\end{array}\right.$ ma distinta...................... 306

$306\left\{\begin{array}{l}\text { Cápsula coronada por los } \\ \text { dos estilos.............. SAXIFragácEas. }\end{array}\right.$

(Fruto de forma distinta.... RosícEAS.

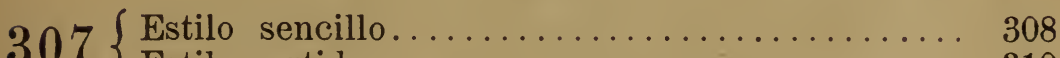

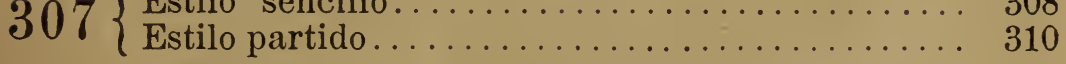

308 Hojas de estipulas interfo-

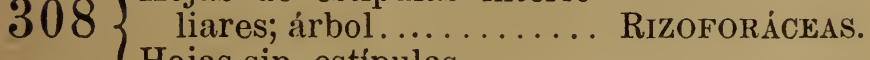

$\{$ Hojas sin estipulas..................... 309

$309\{$ Hojas coriáceas.......... Mirtáceas.

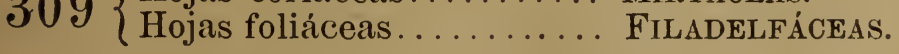

$310\left\{\begin{array}{l}\text { Cápsula coronada por los } \\ \text { dos estilos.............. SAXIFRAGíceas. } \\ \text { Cápsula coronda }\end{array}\right.$

\{ápsula coronada por el cáliz................. Filadelfáceas.

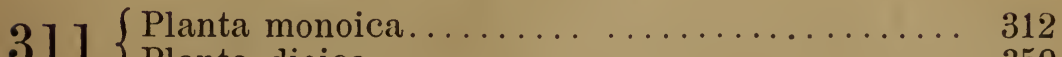

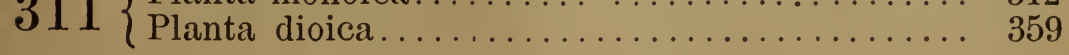


$312\{$ Yerba ó sub-arbusto . ................ 313

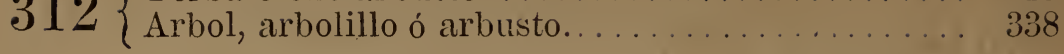

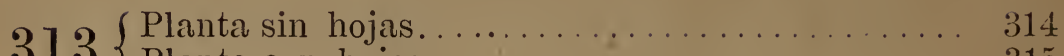

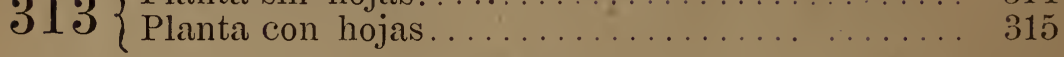

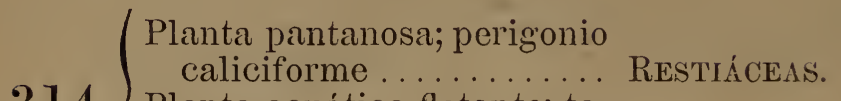

314 Planta acuática flotante; tallo foliáceo ............. Lemnícens.

Planta parásita....................... 337

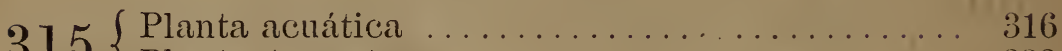

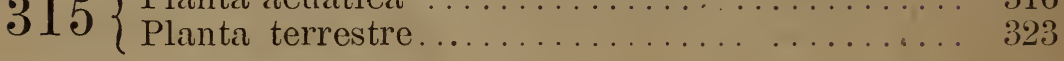

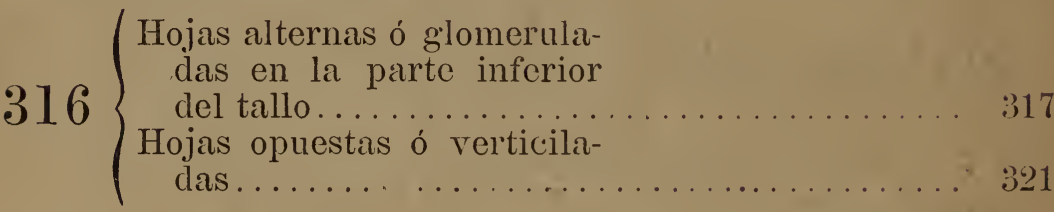

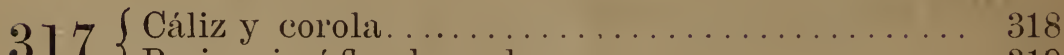

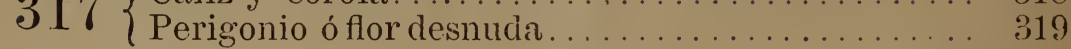

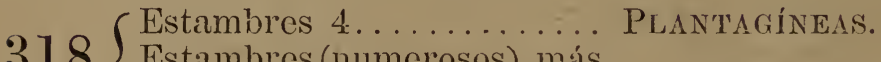

$318\{$ Estambres (numerosos), más de $4 \ldots \ldots \ldots \ldots \ldots$. Alismícenas.

$319\left\{\begin{array}{c}\text { Planta completamente su- } \\ \text { mergida en el agua ó flo- } \\ \text { tante.................................. } \\ \text { Planta que sale prolongada- }\end{array}\right.$ mente de la superficie del ag'ua...

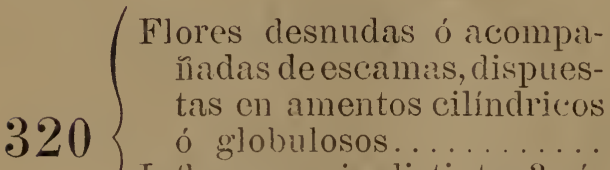
Inflorescencia distinta; 3 pétalos internos petalóideos

( y 3 externos herbáceos.....

T'Tríceas.

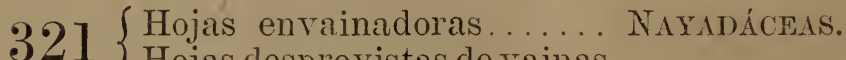

$321\{$ Hojas desprovistas de rainas .............. 322 
$322\left\{\begin{array}{l}\text { Estambre 1; hojas opuestas; } \\ \text { flores desnudas acompa- } \\ \text { hadas de } 2 \text { escamas; } 2 \text { es- } \\ \text { tilos en las femeninas.... Calitricáceas. } \\ \text { Estambres } 10 \text { o más; hojas } \\ \text { verticiladas; perigonio; } 1 \\ \text { estigma en las flores fe } \\ \text { meninas.... ........... Ceratofiláceas. }\end{array}\right.$

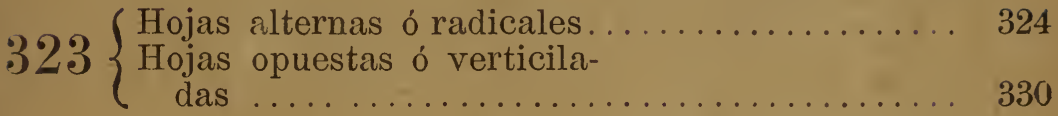

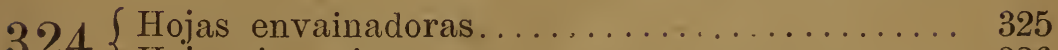

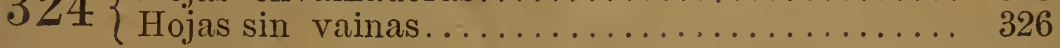

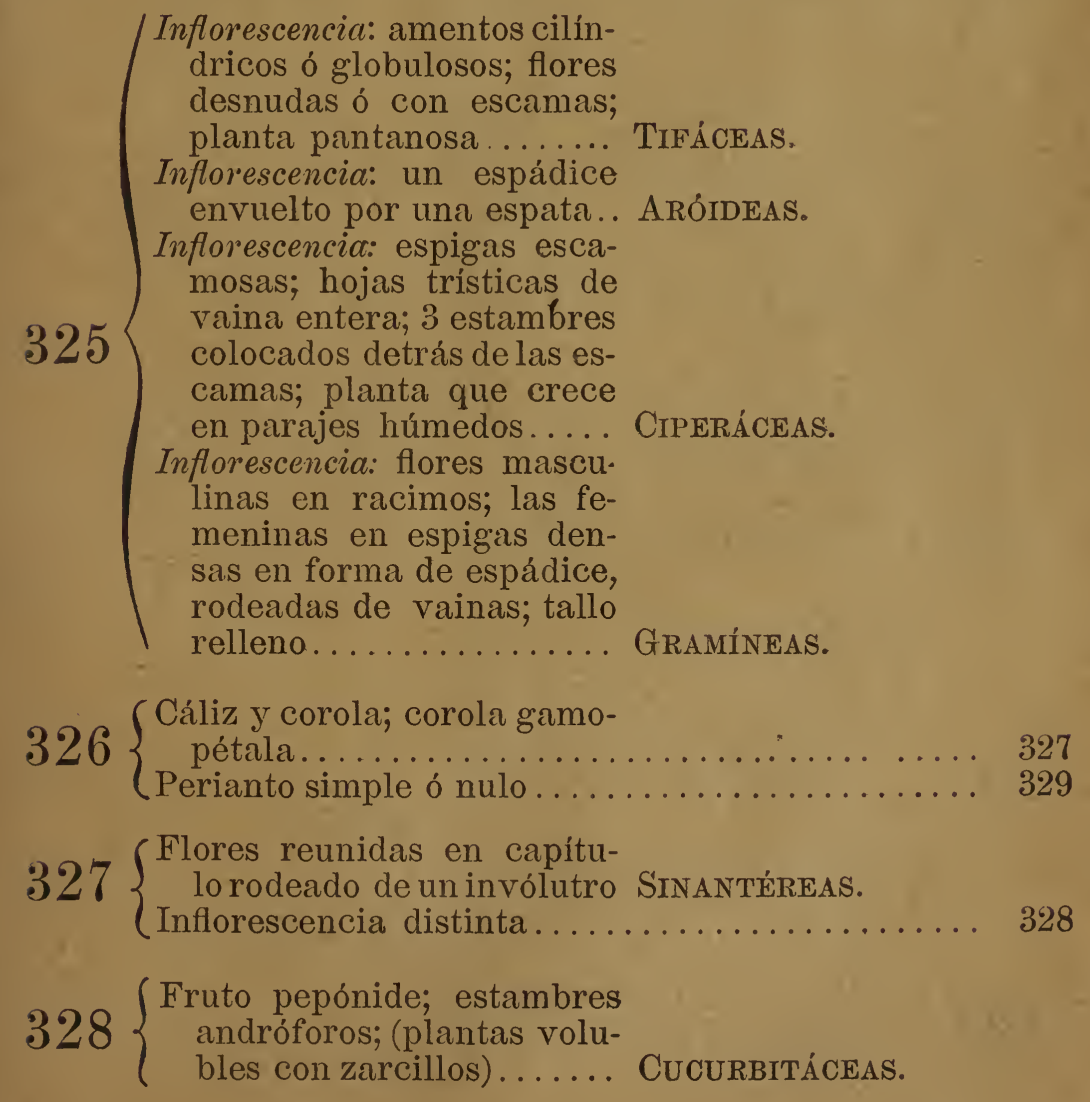


$328\left\{\begin{array}{l}\text { Fruto seco, (tri-coco corona- } \\ \text { do por estigmas sesiles); ju- } \\ \text { go lechoso, (muy irritante) EuforbiáceAs. }\end{array}\right.$

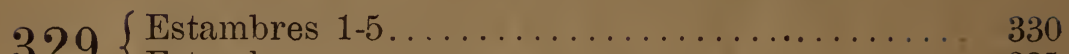

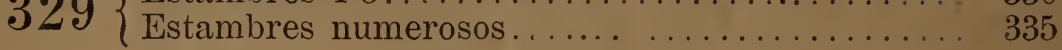

$330\left\{\begin{array}{l}\text { Ovario } 2 \text {-3-locular; (jugo le- } \\ \quad \text { choso irritante) } \ldots \ldots \ldots \ldots \ldots \ldots \ldots \ldots \ldots \ldots \ldots \ldots \ldots \ldots \ldots \ldots \ldots \ldots \ldots \ldots \ldots \\ \text { Ovario 1-locular } \ldots \ldots \ldots \ldots \ldots \ldots \ldots \ldots\end{array}\right.$

$391\left\{\begin{array}{l}\text { Ovario infero } \ldots \ldots \ldots \ldots \ldots \ldots \ldots \ldots \ldots \ldots \ldots \ldots \ldots \ldots \ldots \ldots \\ \text { Ovario } \ldots \ldots \ldots \ldots \ldots\end{array}\right.$

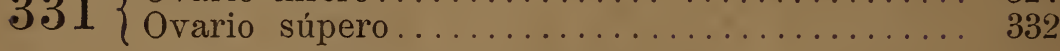

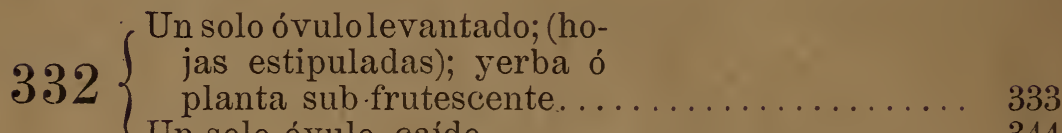

( Un solo óvulo caído.................... 344

Flores desnudas, (con escamas entre ellas); masculinas y femeninas mezcla-

333, das sin orden y dispuestas en amentos; fruto, ba-

ya pequeña monosperma. PiPeráceas.

Perigonio........................ 334

$334\{$ Perigonio seco ó coloreado. AMARANTÁcEas.

$334\left\{\begin{array}{l}\text { Perigonio verde herbáceo.. QUENopodiácEAs. } \\ \text { Pún }\end{array}\right.$

$35\{$ Planta de jugo lechoso ................ 330

$335\left\{\begin{array}{c}\text { Planta } \sin \text { jugo caracterís- } \ldots \ldots \ldots \ldots \ldots \ldots \ldots \ldots \ldots \ldots \ldots \ldots \ldots \ldots \ldots \ldots \ldots \ldots \ldots \ldots \\ \text { tico } \ldots \ldots \ldots \ldots \ldots \ldots \ldots\end{array}\right.$

Estilos 2; estigmas en forma de pincel; espigas esféricas ó cilíndricas; flores inferiores masculinas, sien-

336 do femeninas las superiores................ RosácEas.

Estilos 3 ; hojas partidas en dos partes desiguales y por tanto oblicuas......... BEGonIÁcEAs.

$337\left\{\begin{array}{c}\text { Perigonio de las flores mas- } \\ \text { culinas con } 4-6 \text { divisiones; } \\ 8 \text { anteras } \ldots \ldots \ldots\end{array}\right.$

CITINÁCEAs. 
$337\left\{\begin{array}{l}\text { Perigonio de las flores mas- } \\ \text { culinas con } 3 \text { divisiones } \\ \text { ó nulo; estambres de } 1-3 \\ \text { planta que nace sobre raí- } \\ \text { ces. ................ BALANoforÁCEAs. }\end{array}\right.$

Hojas de estípulas herbá-

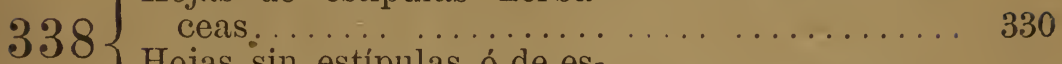

Hojas sin estípulas ó de estípulas caducas.

$339\{$ Tallo es un estípite....... Palmeras.

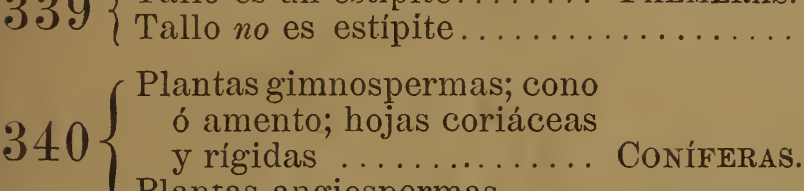

Plantas angiospermas.

Flores en espádice; flores masculinas y femeninas formando 2 espirales al-

$341\{$ ternativas; arbolillo voluble ó planta acaule de hojas grandes bi-palmatífi-

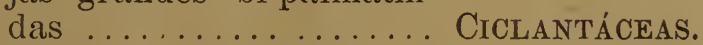

Inflorescencia distinta................. 342

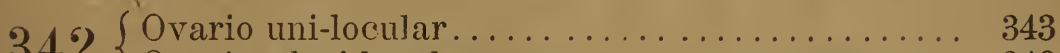

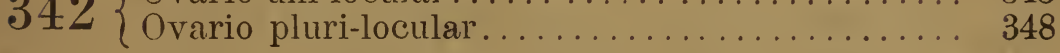

/Hojas sin estípulas; flores generalmente en racimos; cápsula ó drupa monosperma; perianto doble ó

$343\left\{\begin{array}{l}\text { perigonio; (planta recino- } \\ \text { sa ó lechosa)............ Terebintáceas. }\end{array}\right.$

Hojas palmatífidas; flores en cabezuelas; las masculinas, desnudas; cápsula... MIRICÁceas.

Hojas de estípulas caducas.

(Planta de jugo lechoso; hojas alternas; aquenios en

$344\left\{\begin{array}{l}\text { invólucros carnosos ó su- } \\ \text { culentos que forman al pa- }\end{array}\right.$ recer el fruto..........

Planta sin jugo característi- 
$345\left\{\begin{array}{l}\text { Dos estigmas ............. } \\ \text { Un estigma plurifido. }\end{array}\right.$

Flor desnuda; árbol de ho-

$346\{$ jas palmati-lobadas; nue-

$\left\{\begin{array}{c}\text { cecilla } \\ \text { Perigonio }\end{array}\right.$

\section{Platanáceas.}

MoRÁCEas.

ARTOCARPÁceas.

$347\left\{\begin{array}{l}\text { Perigonio de la flor mascu- } \\ \text { lina con } 5 \text { piezas, siendo } \\ \text { gamófilo en la femenina; } \\ 2 \text { estigmas. ........... Canabíneas. } \\ \text { Perigonio } 2 \text { ó } 4 \text {-lobado; } 1 \text { es- } \\ \text { tigma................ Urticáceas. }\end{array}\right.$

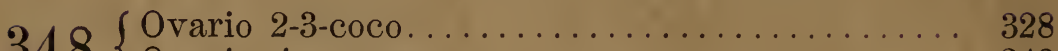

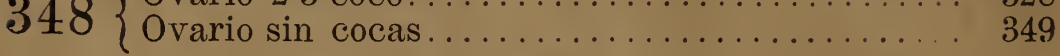

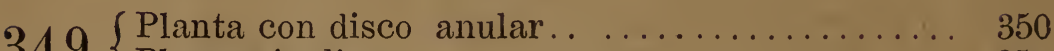

$349\left\{\begin{array}{l}\text { Planta } \sin \text { disco } \ldots \ldots \ldots \ldots \ldots \ldots \ldots \ldots \ldots \ldots \ldots \ldots \ldots \ldots \ldots \ldots \ldots \\ \text { Pla }\end{array}\right.$

$350\left\{\begin{array}{l}\text { Flores en racimo; [hojas com- } \\ \text { puestas }] \ldots \ldots \ldots \ldots \ldots \ldots \text { Terebintáceas. }\end{array}\right.$

Flores axilares; hojas enteras............... Flacurtiáceas.

35lores, al menos las mascu-

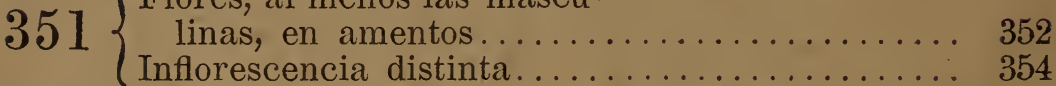

Hojas opuestas, sin estipulas; fruto carnoso coronado por los 2 estilos; flor masculina con 4 sépalos y

$352\left\{\begin{array}{c}4 \text { estambres............... GARRIÁCEAS. } \\ \text { Hojas alternas impari-pinna- }\end{array}\right.$ das, sin estípulas; árbol aromático; drupa........ JUGLANDÁcEAS.

Hojas alternas de estípulas

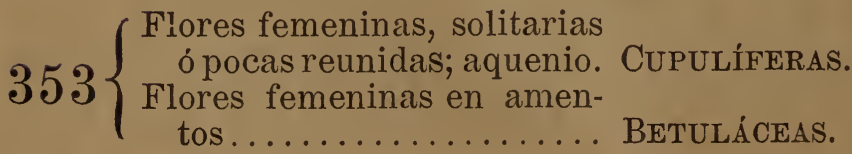


$354\left\{\begin{array}{c}\text { Planta de jugo amarillo; ho- } \\ \text { jas coriáceas; cáliz y co- } \\ \text { rola; ovario súpero....... Gutíveras. } \\ \text { Planta }\end{array}\right.$

Planta sin jugo característico........................... 355

(Arbusto trepador; hojas sen-

355 cillas, alternas; sépalos y pétalos en varias series; muchos carpelos; drupas. Menispermáceas.

Arbol ó arbusto común...

356

Corola gamopétala; ovario

$356\left\{\begin{array}{l}\text { súpero; madera de un tin- } \\ \text { temegro }\end{array}\right.$

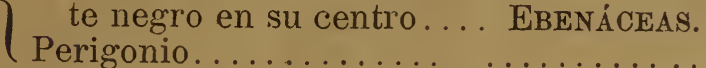

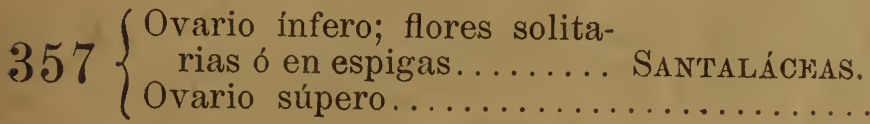

358

Perigonio de 4 ó 6 divisiones; flores en panículas ó cimas; estambres libres dispuestos en dos series: la

$358\left\{\begin{array}{l}\text { interior de anteras extror- } \\ \text { sas, siendo introrsas en la } \\ \text { exterior; éstas }\end{array}\right.$ exterior; éstas se abren por medio de válvulas; planta aromática....... LAURÁcEAs.

Perigonio de 3 divisiones;

estambres monadelfos... Miristicáceas.

Planta parásita sobre diver-

$359\left\{\begin{array}{l}\text { sos árboles; hojas coriá- } \\ \text { ceas y persistentes; [baya }\end{array}\right.$

monosperma]............ Lorantáceas.

(Planta no parásita...................... 36C

$360\{$ Yerba ó sub-arbusto .................. 361

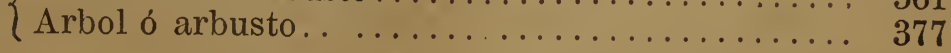

$361\left\{\begin{array}{l}\text { Perianto doble } \ldots \ldots \ldots \ldots \ldots \ldots \ldots \ldots \ldots \ldots \ldots \ldots \ldots \ldots \ldots \ldots \ldots \ldots \ldots \\ \text { Perianto }\end{array}\right.$

$\{$ Perianto simple $\delta$ nulo ..................... 365 


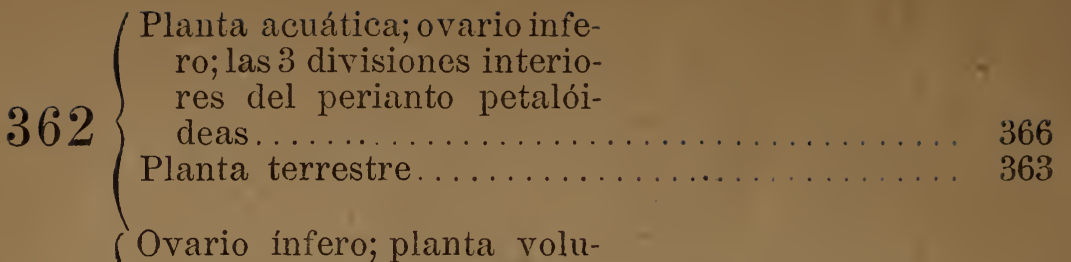

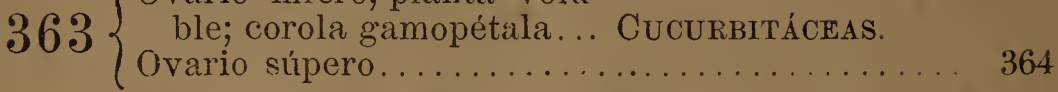

$364\left\{\begin{array}{l}\text { Planta de jugo lechoso..... Eurorbiáceas. } \\ \text { Planta sin jugo caracterís- } \\ \text { co; hojas opuestas, senci- } \\ \text { llas y estrechas......... CARIofILÁCEas. }\end{array}\right.$

$365\left\{\begin{array}{l}\text { Ovario ínfero } \ldots \ldots \ldots \ldots \ldots \ldots \ldots \ldots \ldots \ldots \ldots \ldots \ldots \ldots \ldots \ldots \ldots \ldots \ldots \ldots \ldots \ldots \ldots \ldots \ldots \\ \text { Ovario súpero } \ldots \ldots \ldots \ldots\end{array}\right.$

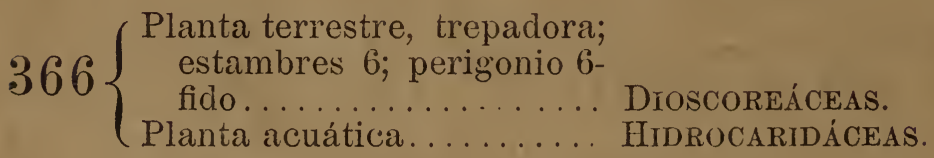

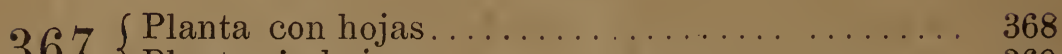

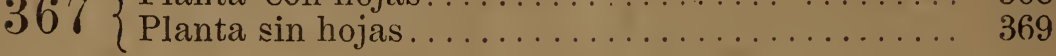

$368\left\{\begin{array}{l}\text { Hojas opuestas ó verticila- } \\ \text { das } \ldots \ldots \ldots \ldots \ldots \ldots \ldots \ldots \ldots \ldots \ldots \ldots \ldots \ldots \ldots \ldots \ldots \ldots \ldots \ldots\end{array}\right.$

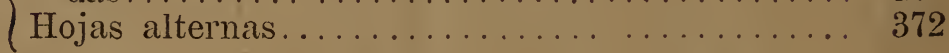

Planta acuática flotante; tallo foliáceo; flores desnudas. . . . . . . . . . . . . . . LeMNÁcEAS. $369\left\{\begin{array}{l}\text { Planta pantanosa; tallo des- } \\ \text { nudo ó cubierto de esca- }\end{array}\right.$ mas; perigonio caliciforme............. Restiáceas.

$370\{$ Planta acuática........ NAYADÁcEAS.

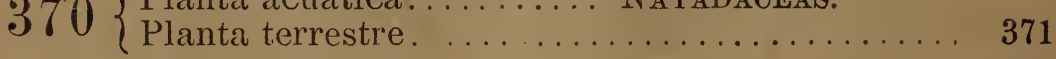

$371\{$ Hojas estipuladas. . . . . . . . . . . . . . 330

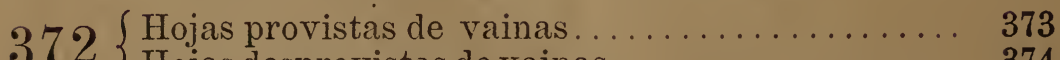

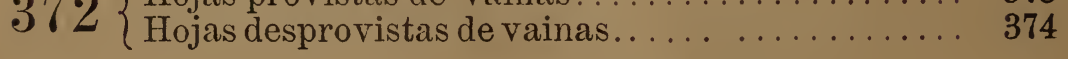


$373\left\{\begin{array}{l}\text { Perianto patente ........... Poligonáce. } \\ \text { Perianto nulo ........... }\end{array}\right.$

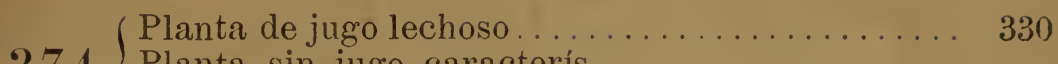

$374\left\{\begin{array}{r}\text { Planta sin jugo caracterís- } \\ \text { tico..................... }\end{array}\right.$ 375

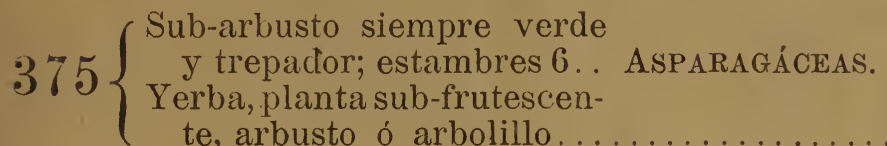

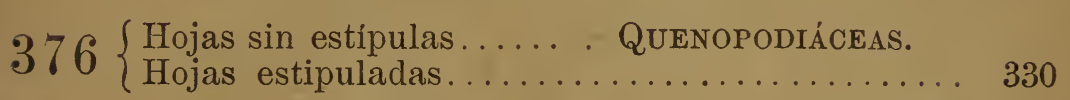

$377\{$ El tallo es un estípite....................................... 378

$377\{$ El tallo no es estipite..................... 379

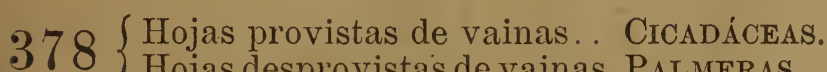

$378\left\{\begin{array}{l}\text { Hojas desprovistas de vainas Palmeras. } \\ \text { Hojas }\end{array}\right.$

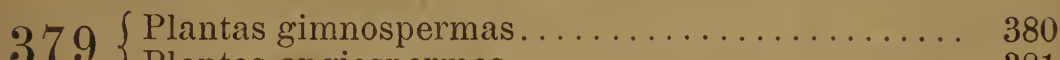

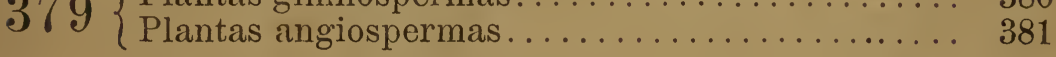

(Flores masculinas desnudas, acompañadas de una es-

$380\left\{\begin{array}{c}\text { cama; (hojas coriáceas y } \\ \text { rígidas)...................... Coníferas. }\end{array}\right.$

Flores masculinas provistas de perianto tubular; (hojas reducidas á escamas) Guenetáceas.

$381\{$ Hojas estipuladas...................... 383

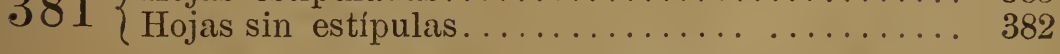

$382\{$ Fruto, sámara........... JaZMináceAs.

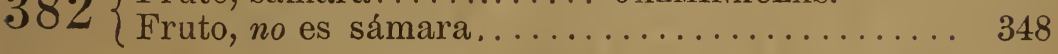

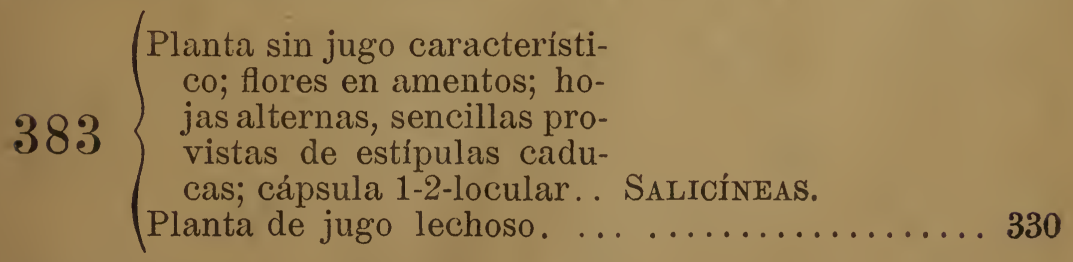
$384\{$ ORIPTÓGAMAS. 


\section{INDICE DE LAS FAMILIAS.}

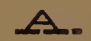

Acantáceas........... 51

Aceráceas.............. 189

Alismáceas......148, 156 y 318

Amarantáceas....... 21 y 334

Amarilidáceas............ 177

Amomáceas............ 28

Ampelidáceas.......... 88

Anonáceas... , ......... 271

Apocináceas............ 112

Aquifoliáceas..... 37, 86 y 117

Araliáceas. .........139 y 141

Aristoloquiáceas.......175 y 302

Aróideas....... 165, 179 y 325

Artocarpáceas ........ ... 345

Asclepiádeas........... . 112

Asparagáceas....157, 160 y 375

Auranciáceas.......... 297

\section{B.}

Balınoforáceas ... . . ... 337

Balsamináceas.......... 81

Begoniáceas.... ........ 336

Berberídeas ......... 38 y 151

Betuláceas............... 353

Bignoniáceas......... 51 y 101

Bombáceas......... 95 y 297

Borragináceas ........... 114

Bromeliáceas... ......... 176

Burmaniáceas ........... 23

Butomáceas............. 204

Büttneriáceas.... 89, 250 y 295

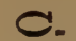

Cabombáceas........... 275

Cactáceas. ................. 298

Caliceráceas
Calitricáceas........... 322

Campanuláceas..... 138 y 142

Canabíneas.......................... 347

Caparídeas............... 285

Caprifoliáceas............... 134 y 138

Cariofiláceas 20,69, 167, 185,

257 y 364

Cedreláceas............ 232

Celastráceas..... ...34 y 40

Ceratofiláceas........... 322

Cesalpiniáceas........... 252

Cicádeas........................... 378

Ciclantáceas............ 341

Ciperáceas....... 18, 325 y 373

Cistáceas. .......2285 y 290

Citináceas................... 337

Colquicáceas............. 164

Columeliáceas........... 23

Combretáceas............. 211

Comelináceas............. 162

Coníferas....... .. 340 y 380

Convolvuláceas.......... 105

Cordiáceas... .... 117 y 248

Cornáceas............ 60

Crasuláceas. . 26, 182, 246 y 268

Crucíferas........... 148 y 151

Cucurbitáceas....... 328 y 363

Cupulíferas............. 353

\section{D.}

Dileniáceas............ 274

Dioscoreáceas........... 366

Dipsáceas..........6.6. 62 y 133

Droseráceas.... 76, 242 y 278

ㅍ.

Ebenáceas......... 154 y 356

Ericáceas.......121, 200 y 247 
Eritroxiláceas.... 94, 225 y 235

Escrofulariáceas .......... 51

Esculáceas............. 190

Estiracáceas... 154, 174 y 247

Euforbiáceas........ 328 y 364

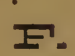

Filadelfáceas....... 309 y 310

Fitolacáceas.......... 186 y 269

Flacurtiáceas........ 272 y 350

Francoáceas............. 276

Fumariáceas.............. 149

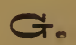

Garriáceas . . ........ 352

Gencianáceas. 43, 104, 152 y 199

Guenetáceas............ 380

Geraniáceas ........ 79 y 230

Gesneriáceas..... 10, 30 y 62

Globulariáceas ....... 49 y 100

Goodeniáceas............ 142

Gramíneas........ 18, 145 y 325

Gutíferas... ...... 290 y 354

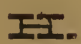

Hamamelídeas.......... 211

Hemodoráceas........ 25 y 177

Hidrocaridáceas .......... 366

Hidrofiláceas............. 102

Hidroleáceas........ 110 y 120

Hipericáceas............. 296

Hipocrateáceas......... 13

\section{I.}

Iridáceas $\ldots \ldots \ldots \ldots 25$ y 27

\section{J.}

Jazmináceas........ 7, 14 y 382

Juglandáceas............ 352

Juncáceas............... 171

Juncagíneas......... 164 y 171

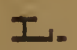

Labiadas............ 8 y 46
Lauráceas. .. 56, 207, 272 y 358

Lemnáceas....... 14, 314 y 369

Lentibulariáceas ........... 10

Liliáceas.................. 163

Lináceas.... ........... 185

Litráceas............ 150 y 291

Loasáceas ........... 276, y 301

Lobeliáceas............ 128

Loganiáceas............... 113

Lorantáceas......... 173 y 359

\section{IM.}

Magnoliáceas....... 267 y 283

Malpighiáceas... 184, 225 y 257

Malváceas............... 295

Melastomáceas............ 260

Meliáceas............. 232

Menispermáceas.......... 355

Mesembriantomáceas...... 303

Miricáceas............... 343

Miristicáceas............. 358

Mirsineáceas............ 106

Mirtáceas........... 305 y 309

Monotropáceas.......... 227

Moráceas................ 345

Musáceas............. 135

\section{IV.}

Nayadáceas... 17, 54, 321 y 370

Nictagíneas. .... 123, 207 y 257

Ninfeáceas......... 275 y 278

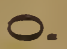

Olacáceas.............. 191

Ocnáceas.............. 93 Onagráceas....... 30, 60 y 214 Orobánqueas........... 44 Orquidáceas............. 28

Oxalídeas........... 186 y 199

\section{P.}

Palmeras....... 169, 339 y 379 Papaveráceas...... .. 38 y 286 Papilionáceas ........... 251 Paroniquiáceas $69,74,237$ y 255 
Pasifloráceas.... 70, 89 y 226

Piperáceas............. 333

Piroláceas .... ... ...... 242

Plantagíneas........ 43 y 318

Platanáceas. ............ 346

Plumbagíneas........ . 71 y 97

Polemoniáceas....... 103 y 120

Poligaláceas......... 196 y 197

Poligonáceas $125,164,167$, 169,205 y 373

Pontederiáceas..... 17, y 163 Portulacáceas 80, 246, 260 y 303 Primuláceas........ 106 y 133

\section{Q.}

Quenopodiáceas.. 21, 334 y 376

\section{I.}

Ramnáceas...... 40, 56 y 141

Ranunculáceas 75, 148, 186 y 292

Resedáceas........ 252 y 292

Restiáceas......... 314 y 369

Ribesiáceas............ 134

Rizoforáceas........2. 211 y 308

Rosáceas.. 20, 74, 255, 306 y 336 Rubiáceas... 61, 1306, 137 y 174 Rutáceas.....11, 91, 195, y 231

\section{S.}

Salicíneas............ 383 Santaláceas...... 58, 131 y 357 Sapindáceas..... I90, 196 y 257
Sapotáceas........ 154 y 248

Saururáceas............ 145

Saxifragáceas 210, 258, 306 y 310 Sinantéreas.......... 129 y 327

Solanáceas....... 101, 110 y 121

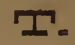

Tamaricáceas.......... 83

Terebintáceas. . 12, 86, 184, 343 y 350

Ternstrœmiáceas 153, 274 y 294

Tifáceas......................... 320 y

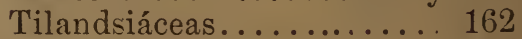

Tiliáceas... . ........... 283

Timeleáceas............... 206

Tropeoláceas.......................... 193

Turneráceas..... ...... 71

\section{U.}

Ulmáceas .............. 124

Umbeliferas.............. 136

Urticáceas............. 347

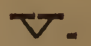

Vacciniáceas.... ...211) y 259

Valerianáceas. ......... 29

Verbenáceas....... 9, 46 y 49

Violáceas.................... 82

$\begin{array}{llll} & & \\ \text { Voquisiáceas..... } & \ldots & \ldots & 13\end{array}$

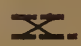

Xiridáceas........... 156 


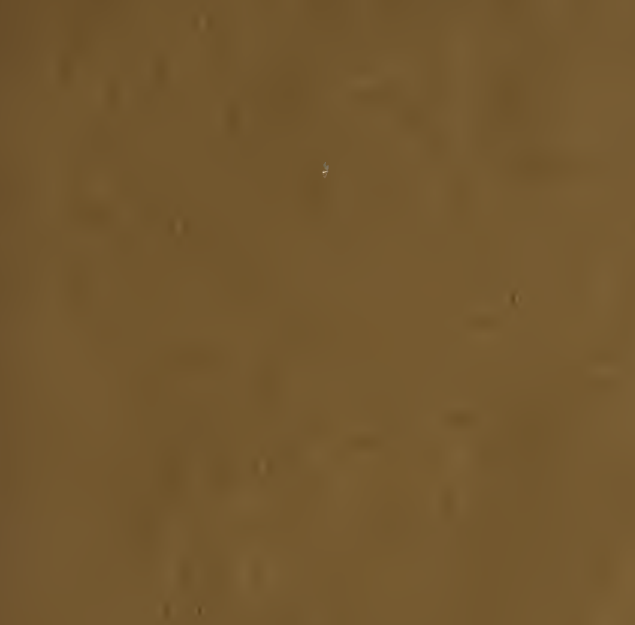

(1)
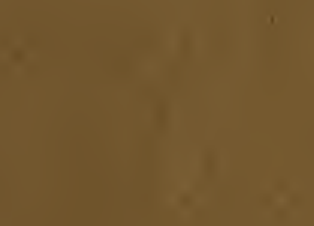

(i)

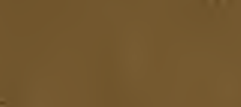

1. $=1$ (1) 1

tan

$-$

Iit
1 $*$ 



\section{$-2$}


3096,6

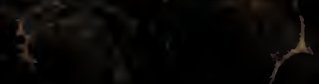

$-4 x^{2}+1$

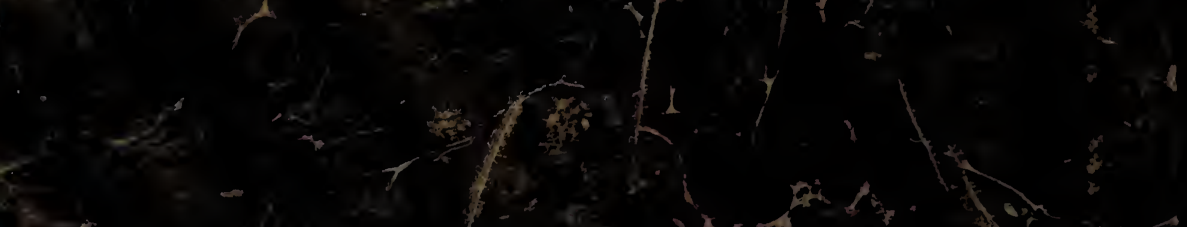

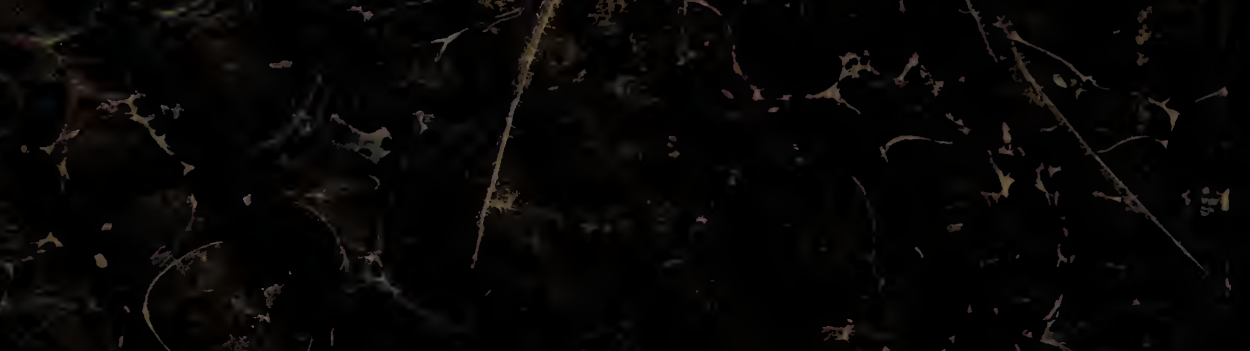

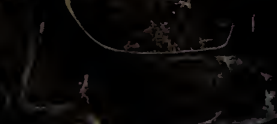

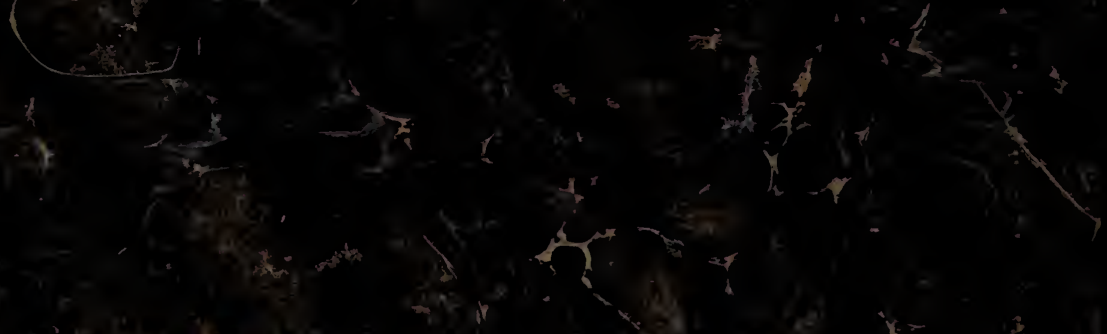

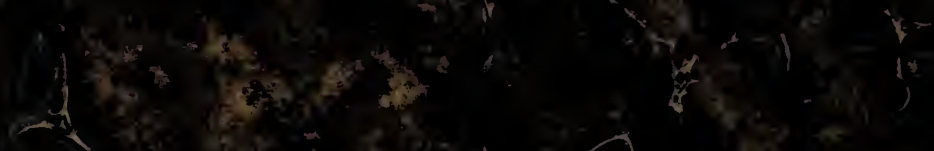

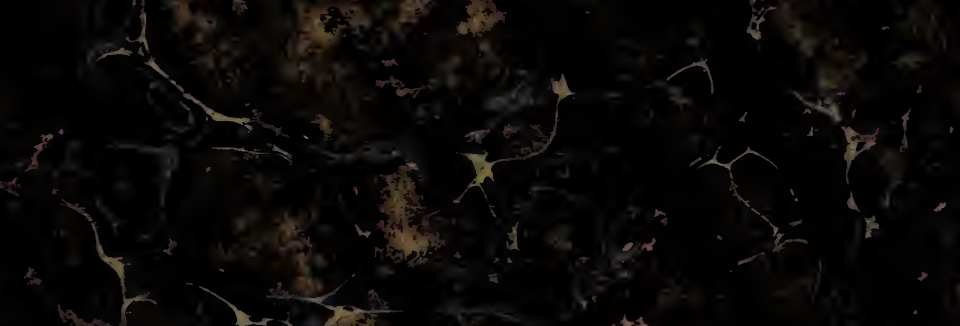

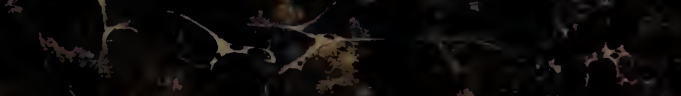

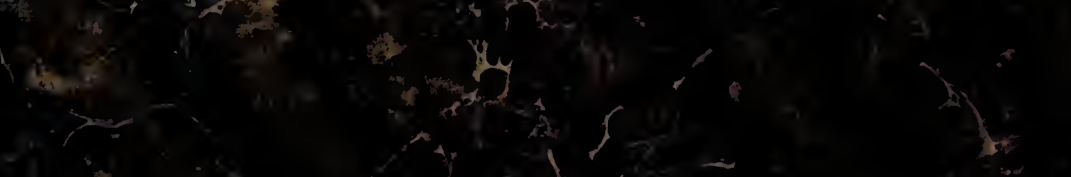

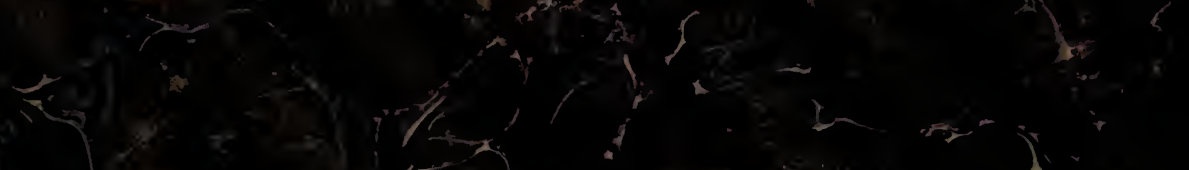

$x \rightarrow x^{2}+12 x$

$\left(x+2 x^{2}+2\right)+2$

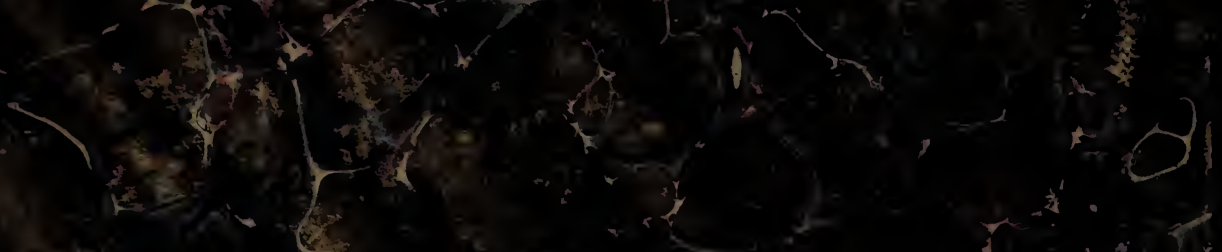

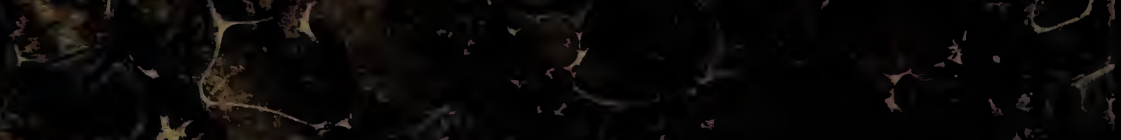

$-2 x^{2}$ t 